NBER WORKING PAPER SERIES

\title{
DOES STRENGTHENING SELF-DEFENSE LAW DETER CRIME OR ESCALATE VIOLENCE? EVIDENCE FROM CASTLE DOCTRINE
}

\author{
Cheng Cheng \\ Mark Hoekstra \\ Working Paper 18134 \\ http://www.nber.org/papers/w18134
NATIONAL BUREAU OF ECONOMIC RESEARCH
1050 Massachusetts Avenue
Cambridge, MA 02138
June 2012

We would like to thank Scott Cunningham, Steve Puller, Joanna Lahey, Erdal Tekin, Chandler McClellan, and Jonathan Meer for providing helpful comments and suggestions. We would like to thank Mark Seaman for providing excellent research assistance. The views expressed herein are those of the authors and do not necessarily reflect the views of the National Bureau of Economic Research.

NBER working papers are circulated for discussion and comment purposes. They have not been peerreviewed or been subject to the review by the NBER Board of Directors that accompanies official NBER publications.

(C) 2012 by Cheng Cheng and Mark Hoekstra. All rights reserved. Short sections of text, not to exceed two paragraphs, may be quoted without explicit permission provided that full credit, including $\mathbb{C}$ notice, is given to the source. 
Does Strengthening Self-Defense Law Deter Crime or Escalate Violence? Evidence from

Castle Doctrine

Cheng Cheng and Mark Hoekstra

NBER Working Paper No. 18134

June 2012, Revised June 2012

JEL No. K0,K14

\begin{abstract}
From 2000 to 2010, more than 20 states passed laws that make it easier to use lethal force in self-defense. Elements of these laws include removing the duty to retreat in places outside of one's home, adding a presumption of reasonable belief of imminent harm, and removing civil liability for those acting under the law. This paper examines whether aiding self-defense in this way deters crime or, alternatively, increases homicide. To do so, we apply a difference-in-differences research design by exploiting the within-state variation in law adoption. We find no evidence of deterrence; burglary, robbery, and aggravated assault are unaffected by the laws. On the other hand, we find that homicides are increased by around 8 percent, and that these homicides are largely classified by police as murder. This suggests that a primary consequence of strengthened self-defense law is a net increase in homicide. Finally, we present back-of-the-envelope calculations using evidence on the relative increase in reported justifiable homicide, along with assumptions about the degree and nature of underreporting, to assess whether the entire increase was legally justified.
\end{abstract}

\author{
Cheng Cheng \\ Department of Economics \\ Texas A\&M University \\ 4228 TAMU \\ College Station, TX 77843 \\ chencheng4@neo.tamu.edu \\ Mark Hoekstra \\ Department of Economics \\ Texas A\&M University \\ 3087 Allen Building \\ 4228 TAMU \\ College Station, TX 77843 \\ and NBER \\ markhoekstra@tamu.edu
}




\section{Introduction}

A long-standing principle of English common law, from which most of U.S. self-defense law is derived, is that one has a "duty to retreat" before using lethal force against an assailant. The exception to this principle is when one is threatened by an intruder in one’s own home, as the home is one's "castle”. In 2005, Florida became the first in a recent wave of states to extend castle doctrine to places outside the home, and to expand self-defense protections in other ways. Since then, more than 20 states have followed in strengthening their self-defense laws by passing versions of "castle doctrine" or "stand-your-ground" laws. While the specific components vary across states, the laws eliminate the duty to retreat from a list of specified places, and often remove civil liability for those acting under the law and establish a presumption of reasonableness as to the beliefs and actions of the individual claiming self-defense. For ease of exposition, we subsequently refer to these laws as castle doctrine laws.

These laws alter incentives in two important ways. First, the laws reduce the expected cost of using lethal force. Castle doctrine lowers the expected legal costs associated with defending oneself against criminal and civil prosecution, as well as the probability that one is ultimately found criminally or civilly liable for the death or injury inflicted. In addition, the laws increase the expected cost of committing violent crime, as victims are more likely to respond by using lethal force. The purpose of our paper is to examine empirically whether people respond to these incentives, and thus whether the laws lead to an increase in homicide, or to deterrence of crime more generally.

In doing so, our paper also informs a vigorous policy debate over these laws. 
Proponents argue these statutes provide law-abiding citizens with additional necessary protections from civil and criminal liability. They argue that since the decision to use lethal force is a split-second one that is made under significant stress, the threatened individual should be given additional legal leeway. Critics argue that existing self-defense law is sufficient to protect law-abiding citizens, and extending their scope will unnecessarily escalate violence. These potential consequences have been of particular interest recently following some highly publicized cases. ${ }^{1}$ In examining the empirical consequences of these laws, this study informs the debate over their costs and benefits.

We use state-level crime data from 2000 to 2010 from the FBI Uniform Crime Reports to empirically analyze the effects of castle doctrine on two types of outcomes. First, we examine whether these laws deter crimes such as burglary, robbery, and aggravated assault. In doing so, we join a much larger literature on criminal deterrence generally (e.g., Becker, 1968; Ehrlich, 1973; Di Tella and Schargrodsky, 2004; Donohue and Wolfers, 2009). More specifically, however, we join a smaller literature focused on whether unobserved victim precaution can deter crime. For example, Ayres and Levitt (1998) examine whether LoJack reduces overall motor vehicle thefts, while others have examined whether laws that make it easier to carry concealed weapons deter crime (Bronars and Lott, 1998; Dezhbakhsh and Rubin, 1998; Lott and Mustard, 1997; Ludwig, 1998). ${ }^{2}$

\footnotetext{
${ }^{1}$ The most publicized case is that of Trayvon Martin, an unarmed teenager who was shot and killed by a neighborhood watch volunteer (Alvarez, 2012).

${ }^{2}$ Our view is that relative to shall-issue concealed carry laws, the potential for castle doctrine law to deter crimes is quite large. For example, in Texas only 1.5 percent of adults age 18 and older have a concealed carry permit, and presumably only a fraction of those carry a gun on a regular basis (Texas Department of Public Safety, 2006; Texas Department of State Health Services, 2006; and author's calculations). In contrast, Gallup polls indicate that from 2000 to 2009,44 percent of households own a gun that could be used in self-defense against a burglar or assailant (Saad, 2011). Moreover, strengthened self-defense laws lower the cost of using a concealed carry weapon.
} 
We then examine whether lowering the expected cost of using lethal force results in an increase in homicide, defined as the sum of murder and non-negligent manslaughter. We also examine the effects of the laws on other outcomes in order to shed light on why homicides are affected by the laws.

To distinguish the effect of the laws from confounding factors, we exploit the within-state variation in the adoption of laws to apply a difference-in-differences identification strategy. Intuitively, we compare the within-state changes in outcomes of states that adopted laws to the within-state changes in non-adopting states over the same time period. Moreover, we primarily identify effects by comparing changes in castle doctrine states to other states in the same region of the country by including Census region-by-year fixed effects. Thus, the crucial identifying assumption is that in the absence of the castle doctrine laws, adopting states would have experienced changes in crime similar to non-adopting states in the same region of the country. Our data allow us to test and relax this assumption in several ways. First, we empirically test whether outcomes in the two groups of states diverge in the year prior to adoption. In addition, we show that our findings are robust to the inclusion of time-varying covariates such as demographics, policing, economic conditions, and public assistance, as well as to the inclusion of contemporaneous crime levels unaffected by castle doctrine laws that proxy for general crime trends. Along similar lines, we offer placebo tests by showing that castle doctrine laws do not affect crimes that ought not be deterred by the laws, such as vehicle theft and larceny. Failing to find effects provides further evidence that general crime trends were similar in adopting and non-adopting states. Finally, we allow for 
state-specific linear time trends.

Results indicate that the prospect of facing additional self-defense does not deter crime. Specifically, we find no evidence of deterrence effects on burglary, robbery, or aggravated assault. Moreover, our estimates are sufficiently precise as to rule out meaningful deterrence effects.

In contrast, we find significant evidence that the laws lead to more homicides. Estimates indicate that the laws increase homicides by a statistically significant 8 percent, which translates into an additional 600 homicides per year across states that adopted castle doctrine. The magnitude of this finding is similar to that reported in a new paper by McClellan and Tekin (2012), who examine these laws' effect on firearm-related homicide using death certificate data from Vital Statistics. ${ }^{3,4}$ We further show that this divergence in homicide rates at the time of castle doctrine enactment is larger than any divergence between the same groups of states at any time in the last 40 years, and that magnitudes of this size arise rarely by chance when randomly assigning placebo laws in similarly-structured data sets covering the years prior to castle doctrine. In short, we find compelling evidence that by lowering the expected costs associated with using lethal force, castle doctrine laws induce more of it.

This increase in homicides could be due either to the increased use of lethal force

\footnotetext{
${ }^{3}$ One advantage of using FBI UCR data is that it allows us to assess both how the laws affect the use of lethal force and whether they deter violent crime. In addition, the nature of the UCR data enables us to measure all homicides, rather than just those caused by firearms. The data also allow us to examine homicide subclassifications and relative changes in reported justifiable homicide from the SHR, along with assumptions about the degree of underreporting, to address the issue of whether the additional homicides are legally justified. This is not possible using data originating from death certificates. The primary disadvantage of the UCR homicide data is that while the annual state-level data we use are regarded as accurate and there is no reason to believe that any total homicide reporting issue at any level should be systematically correlated with changes in castle doctrine law, the monthly data from Vital Statistics are more complete. ${ }^{4}$ Our findings contrast with those of Lott (2010) in More Guns, Less Crime, who reports that castle doctrine laws adopted from 1977 through 2005 reduced murder rates and violent crime.
} 
in self-defense situations that are classified by police as murder, or to the escalation of violence in otherwise non-lethal conflicts. In an attempt to shed light on whether the increase is driven entirely by legally justified homicide, we look at two things. For evidence of escalation by criminals, we look at whether criminals are more likely to carry a gun while committing robbery, and whether there is an increase in felony-type and suspected felony-type murder, in which a murder is committed during the commission of another felony. There is little robust evidence of an increase in criminals' propensity to carry a weapon. Estimated effects on felony-type and suspected felony-type murder are positive and large, but imprecisely estimated.

In addition, we look at justifiable homicide, which is a separate classification available in the Supplemental Homicide Reports. One concern with these data is underreporting; Kleck (1988) estimates that only one-fifth of legally justified homicides are classified that way by police. Nevertheless, we would still expect relative changes in reported justifiable homicides before and after the laws to be informative, and show that while our best back-of-the-envelope estimate is that roughly half of the additional homicides caused by castle doctrine are legally justified, stronger assumptions about the degree of underreporting (e.g., one-tenth compared to one-fifth) can lead one to conclude that all of the additional homicides caused by castle doctrine are legally justified. We emphasize that any conclusion depends on assumptions regarding the degree and nature of underreporting of justifiable homicide by police. ${ }^{5}$

Collectively, these findings suggest that incentives do matter in one important

\footnotetext{
${ }^{5}$ Of course, there is also the issue of whether all legally justified homicides under castle doctrine are socially desirable, which is beyond the scope of this paper.
} 
sense: lowering the threshold for the justified use of lethal force results in more of it. On the other hand, there is also a limit to the power of incentives, as criminals are apparently not deterred by empowering victims to use lethal force to protect themselves.

These findings also have significant policy implications. The first is that these laws do not appear to offer any hidden spillover benefits to society at large. Rather, the evidence indicates that the benefits of strengthening self-defense laws begin and end with the added protections to actual victims of violent crime. On the other hand, the primary potential downside of the law is the increased number of homicides. Thus, our view is that any evaluation of these laws ought to weigh the benefits of increased self-defense against the net increase in loss of life caused by the laws.

\section{Castle Doctrine Law and Identification}

\subsection{Castle Doctrine Law}

U.S. self-defense law, which stems from English common law, has long favored the principle of "retreat to the wall”, which means that only after no longer being able to retreat safely could one respond to an attacker with deadly force (Vilos and Vilos, 2010). The exception to this rule is if the attack is inside one's home, or "castle”, in which case there is no longer a duty to retreat. In 2005, a wave of states began removing the duty to retreat from places outside the home, as well as strengthening self-defense laws in several other ways. For example, most laws added language that explicitly states individuals are justified in using deadly force in certain circumstances when they reasonably believe that they face a serious risk of imminent death or serious bodily harm. In addition, castle 
doctrine laws removed the duty to retreat in a list of special places such as one's vehicle, place of work and, in some cases, any place one has a legal right to be. Additionally, many of these laws also added a presumption of reasonable fear of imminent serious injury or death, which shifts the burden of proof to the prosecutor to show someone acted unreasonably. ${ }^{6}$ Similarly, many laws also grant immunity from civil liability when using defensive force in a way justified under law. Collectively, these laws lower the cost of using lethal force to protect oneself, though they also lower the cost of escalating violence in other conflicts.

Our understanding is that the main rationale for these laws was to provide additional legal leeway to potential victims in self-defense situations, not to deter crime. Thus, there is little reason to believe that the enactment of these laws coincided with either other policies expected to affect crime or homicides, or with expectations about future crime. $^{7}$

To determine if and when states passed castle doctrine laws, we searched news releases and other sources such as the Institute for Legislative Action of the National Rifle Association to determine whether a state appeared to have passed a law that strengthened self-defense law these ways. Specifically, we coded the specific attributes of each state statute found, and classified whether the law i) removed the duty to retreat from somewhere outside the home, ii) removed the duty to retreat from any place one has a legal right to be,

\footnotetext{
${ }^{6}$ For example, the law passed in Florida states that "a person is presumed to have held a reasonable fear of imminent peril of death or bodily injury to himself or herself or another when using defensive force that is intended or likely to cause death or bodily injury to another."

${ }^{7}$ The National Rifle Association (NRA) was a major proponent of these laws (Goode, 2012). We are unaware of any statement by the NRA that suggests their support for the laws is due to a belief that the law will deter crime, or that the law is a necessary response to recent changes in violent crime. Rather, our understanding is that supporters view castle doctrine as an issue of individual and victim rights.
} 
iii) added a presumption of reasonable fear for the person using lethal force, and iv) removed civil liability for those acting under the law. We then classified a state as having a castle doctrine law if they remove the duty to retreat in some place outside the home. Our goal in doing so was to create a list of states that extended castle doctrine and generally passed meaningful changes to their self-defense law that would be widely reported. ${ }^{8}$

Table 1 shows the list of states classified as those enacting castle doctrine between 2000 and 2010. We classify 21 states as having passed castle doctrine laws, as each of these states extended the castle doctrine to places outside the home. ${ }^{9}$ Of these, 17 states removed the duty to retreat in any place one has the legal right to be, 13 included a presumption of reasonable fear, and 18 explicitly removed civil liability. Our main analysis groups all of these laws together, and thus captures the average effect of passing a law similar to those passed in these 21 states. However, since that approach is perhaps unnecessarily blunt, in appendix Table A1 we show results from different subgroups and find that the results are largely similar to the average effects. We note, however, that due to the high degree of collinearity and the potential for interaction effects, distinguishing between effects caused by different attributes of these laws is difficult.

\footnotetext{
${ }^{8}$ We are aware of four states that passed laws removing civil liability that that made no other changes to self-defense law over this time period, including Idaho (2006), Maryland (2010), Maine (2007), and Illinois (2004). We do not code those states as castle doctrine states. We also do not classify Wyoming as having passed a castle doctrine law, though we note that they removed civil liability and added a presumption of reasonable fear (provisions that removed the duty to retreat were stripped out prior to passage) (Vilos and Vilos, 2010). Finally, we note that in an earlier version of the paper we defined these laws somewhat more broadly, and somehow missed that Oklahoma passed a castle doctrine law on November $1^{\text {st }}$ of 2006. We thank McClellan and Tekin (2012) for helpful conversations about the specific attributes of laws passed in different states.

${ }^{9}$ To avoid confusion over which states are driving the within-state variation used in our study, we intentionally leave states off Table 1 if they had passed a law that extended castle doctrine prior to 2000 or after 2010, which are outside our sample period.
} 


\subsection{Crime Data}

Outcome data come from the FBI Uniform Crime Reports (UCR) and cover all 50 states from 2000 - 2010. ${ }^{10}$ Specifically, we use homicide, burglary, robbery, and aggravated assault data from the official UCR data published online by the FBI. ${ }^{11}$ In addition, for the other variables not available from the online UCR, we use data from the FBI’s Master files (Return A and Supplemental Homicide Report).

We use these data to test whether making it easier for individuals to use lethal force in self-defense deters crime or increases homicide. For deterrence, we focus on three criminal outcomes. The first is burglary, which is defined as "the unlawful entry of a structure to commit a felony or a theft” (FBI, 2004). The second is robbery, defined as "the taking or attempting to take anything of value from the care, custody, or control of a person or persons by force or threat of force or violence and/or by putting the victim in fear" (FBI, 2004). Finally, we also examine aggravated assault, which the FBI defines as "an unlawful attack by one person upon another for the purpose of inflicting severe or aggravated bodily injury”, and is typically accompanied by the use of a weapon (FBI, 2004). ${ }^{12}$ In all cases, one might expect rational criminals to be less likely to commit such crimes under castle doctrine, as the increased scope for the use of justifiable lethal force on

\footnotetext{
10 There are relatively few cases of missing data. Data on whether robbery was committed with a gun were missing from 2000 to 2005 for Illinois. Justifiable homicide data were missing for Florida, so we requested and received those data directly from the Florida Department of Law Enforcement Office.

${ }^{11}$ These data include corrections by the FBI to adjust for under-reporting by police agencies. We note, however, that results are qualitatively and quantitatively similar if we instead use data from the Supplemental Homicide Report and Return A from the FBI Master files, which were acquired directly from the FBI and include statistics reported after the deadline, but do not correct for under-reporting. For example, estimates corresponding to the homicide estimates in the 6 columns of Panel A in Table 5 are 0.0853, 0.0926, 0.0850, 0.0892, 0.0729, and 0.128, respectively. All are significant at the 1 percent level.

12 Results are similar using data on all assaults, including simple assault, which were obtained from Return A of the FBI Master files.
} 
the part of the victim raises the expected cost to the criminal. ${ }^{13}$

Our last set of outcomes is intended to measure the escalation of violence. The primary outcome we examine is total homicides, which is defined as the sum of murder and non-negligent manslaughter, although we also look at murder separately to determine exactly how police are classifying the additional homicides. ${ }^{14}$

An increase in homicide could represent either an increase in legally justified homicide that is reported as murder or non-negligent manslaughter, or the escalation of violence by criminals, or the escalation of violence in otherwise non-violent situations. ${ }^{15}$ In order to shed light on that issue, we look at two other outcomes, both of which measure the escalation of violence by criminals in response to castle doctrine. The ratio of robberies committed with a gun measures whether criminals respond by being more likely to carry and use weapons during the commission of a crime, as one might expect if they believe they will be faced with lethal force by the victim. We also look at felony-type and suspected felony-type murders, which also measure the escalation of violence by criminals. We expect to see increases in these outcomes if castle doctrine laws induce criminals to be more likely to carry and use deadly weapons during the commission of crimes.

In addition, we also ask whether the laws increase homicides that are reported to the FBI as "justifiable homicides by private citizens", which the FBI defines as "the killing of a felon during the commission of a felony” (Uniform Crime Reporting Handbook,

\footnotetext{
${ }^{13}$ To the extent castle doctrine increases homicide, however, the hierarchy rule means that our results are (slightly) biased in favor of finding deterrence effects. The hierarchy rule instructs reporting agencies to only code the highest, or most serious, offense in multiple-offense situations. Thus, a burglary that escalates into a homicide due to castle doctrine will be coded as a homicide, which would lead us to (slightly) overstate the magnitude of deterrence.

${ }^{14}$ Homicide figures come from the UCR data published online and do not include justifiable homicides. Murder figures come from the FBI's Return A, since murder is not available as a separate category in the published UCR.

${ }^{15}$ The general possibility that disputes can escalate dramatically in environments perceived to be dangerous is discussed in O'Flaherty and Sethi (2010).
} 
2004). The major disadvantage of these data is that they are widely believed to be underreported; Kleck (1988) estimates that around one-fifth of legally justified homicides are reported that way to the FBI. However, note that we use these data only to look for evidence of relative changes in legally justified homicide, and then use those estimates along with varying assumptions about the degree of underreporting in order to determine if the entire increase in homicides can be explained by legally justified homicide. What would complicate our analysis is if reporting changed over time in a way that was systematically correlated with the passage of castle doctrine. While the FBI Uniform Crime Reporting Handbook makes it look to us that this should not be the case, ${ }^{16}$ our view is that if anything, police agencies are probably more likely to report homicides as justifiable after the passage of these laws. Thus, we interpret our estimates as upper bounds on the relative effect of castle doctrine on legally justifiable homicide.

The data also allow us to perform several placebo, or falsification tests. For example, because the focus of castle doctrine laws is on civilians, and not law enforcement, we examine whether we detect effects of the laws on justifiable homicide by police. Similarly, we use data on the rate of larceny and motor vehicle theft to determine whether

\footnotetext{
${ }^{16}$ For example, the handbook emphasizes that "law enforcement agencies must report the willful (non-negligent) killing of one individual by another, not the criminal liability of the person or persons involved" (Uniform Crime Reporting Handbook, 2004). In addition, the handbook emphasizes that by definition, justifiable homicide occurs in conjunction with other offenses, and those other offenses must be reported. The handbook explicitly states that "reporting agencies should take care to ensure that they do not classify a killing as justifiable or excusable solely on the claims of self-defense or on the action of a coroner, prosecutor, grand jury, or court” (Uniform Crime Reporting Handbook, 2004). Additionally, the handbook gives examples of specific hypothetical events that would and would not qualify as justifiable homicide under the guidelines. An example given of an incident that would qualify as a justifiable homicide is "When a gunman entered a store and attempted to rob the proprietor, the storekeeper shot and killed the felon" (Uniform Crime Reporting Handbook, 2004). Note that in the absence of castle doctrine law, this may not qualify as a self-defense case (though it could, of course), but according to the guidelines should still have been reported as a justifiable homicide. An example of what would NOT qualify as a justifiable homicide is "While playing cards, two men got into an argument. The first man attacked the second with a broken bottle. The second man pulled a gun and killed his attacker. The police arrested the shooter; he claimed self-defense” (Uniform Crime Reporting Handbook, 2004). Note here that under castle doctrine, the shooter may well have been justified as acting in self-defense, though again the reporting handbook explicitly states that this would not qualify as a justifiable homicide under the guidelines.
} 
castle doctrine laws appear to affect those crimes. ${ }^{17}$ In both cases we expect to find no effects so long as the identifying assumptions of our difference-in-difference research design hold, which we discuss at length in the next section.

Finally, we have data on several time-varying control variables. Specifically, we have measures of the number of full-time equivalent police per 100,000 state residents (Uniform Crime Reports, 2000-2010). We also include both contemporaneous and lagged measures of the number of persons incarcerated in state prison per 100,000 residents (Bureau of Justice Statistics Bulletin, 2000-2010). These variables capture the effects of deterrence and incapacitation caused by additional policing or incarceration. In addition, we have two variables from the American Community Survey of the U.S. Census Bureau that measure local legal opportunities, including median family income and the poverty rate. We also have data on the share of white and black men in the 15-24 and 25-44 age groups for each state over time (American Community Survey, 2000-2010). Finally, we measure the generosity of public assistance in each state by measuring per capita spending on assistance and subsidies and per capita spending on public welfare (US Census, 2000 2010).

\section{Identification}

To distinguish the effect of the castle doctrine laws from confounding factors, we exploit the within-state variation induced by the fact that 21 states passed such laws between 2000 and 2010. Specifically, we use a difference-in-differences research design

\footnotetext{
${ }^{17}$ While it may be possible for castle doctrine law to deter these crimes as well, our view is that deterrence should be considerably less likely for these crimes than for burglary, robbery, and aggravated assault.
} 
that asks whether outcomes change more in states that adopt castle doctrine laws than in states that do not, and focus primarily on within-region comparisons.

Formally, we estimate fixed effects ordinary least squares (OLS) panel data models, where we typically use the log of the outcome per 100,000 population as the dependent variable. In addition, because a significant number of states report zero justifiable homicides in a given year, we estimate a fixed effects negative binomial model for that outcome as well as OLS models that use the number of justifiable homicides as the dependent variable and control for population on the right-hand side. Ordinary least squares models are estimated with and without weighting by state population. The OLS model estimated is

Outcome $_{i t}=\beta_{1} C D L_{i t}+\beta_{1} X_{i t}+c_{i}+u_{t}+\varepsilon_{i t}$ where $C D L_{i t}$ is the treatment variable that equals the proportion of year $\mathrm{t}$ in which state $\mathrm{i}$ has an effective castle doctrine law, $X_{i t}$ is the vector of control variables, and $c_{i}$ and $u_{t}$ control for state and year fixed effects, respectively. In addition, in most models we also include Census region-by-year fixed effects, to allow states in different regions of the country to follow different trajectories and account for differential shocks by region over time. ${ }^{18}$ Note that for states that enacted the law partway through a year, we set CDL equal to the proportion of the year in which the law was in effect. Robust standard errors are clustered at the state level, though we also do additional exercises in the spirit of Bertrand, Duflo, and Mullainathan (2004) to ensure standard errors are being estimated accurately, as well as to perform inference using placebo estimates from simulated pre-castle doctrine data.

\footnotetext{
18 There are four Census Regions: West, Midwest, Northeast, and South.
} 
This last approach of using distributions of placebo estimates to do inference is similar in spirit to the permutation inference approach used in the synthetic control method by Abadie, Diamond, and Hainmueller (2010).

Since we primarily rely on specifications that include state fixed effects and region-by-year fixed effects, the identifying assumption is that in the absence of the castle doctrine laws, adopting states would have experienced changes in crime similar to non-adopting states in the same region of the country. Our data allow us to test and relax this identifying assumption in several ways. First, we offer a formal statistical test of this by including an indicator in equation (1) for the year prior to the passage of the laws. That is, we ask whether states that pass the laws diverge even before they pass the laws. If they do, it suggests that the identifying assumption of our research design is violated.

We also examine whether time-varying determinants of crime are orthogonal to the within-state variation in castle doctrine laws. Under our identifying assumption, factors such as economic conditions, welfare spending, and policing intensity should not change more over time in adopting states than non-adopting states, as this would suggest that crime in the two groups might have diverged even in the absence of treatment. Thus, we examine whether adding these controls changes our estimates in a meaningful way. To the extent that our difference-in-differences estimates remain unchanged, it provides some assurance that our research design is reasonable. ${ }^{19}$

Along similar lines, we also show results from specifications that include contemporaneous motor vehicle theft and larceny as controls. While it is possible that

\footnotetext{
${ }^{19}$ The primary concern is not that observed determinants vary systematically over time-we can control for those variables directly — but that if they do, it may suggest that unobserved determinants also change systematically over time in the treatment and control groups.
} 
castle doctrine laws could affect these crimes, we would expect any such effects to be second-order and at most small in magnitude. Thus, we use these crime measures as controls that pick up any differential trends in crime in adopting and non-adopting states. We also perform falsification exercises using these crimes as outcomes to explicitly test whether castle doctrine laws appear to affect crimes unrelated to self-defense. If our identifying assumption holds, we would expect to see no effects on these crimes.

Finally, we allow for state-specific linear time trends, thereby allowing each state to follow a different trend.

\section{Results}

\subsection{Falsification Tests}

One way to test the identifying assumption is to directly examine whether crimes that ought not be affected by the laws - and thus proxy for general crime trends - appear to be affected by the laws. ${ }^{20}$ Finding effects on crimes that ought to be exogenous to castle doctrine law would invalidate our research design.

Thus, we examine whether castle doctrine laws appear to affect larceny or motor vehicle theft. While it is possible that these outcomes are affected directly by self-defense laws, we argue that such effects should be second-order, at best.

Results are shown in Table 3, which uses a format similar to subsequent tables showing other outcomes. Columns 1 through 6 represent OLS estimates that are weighted by population, while Columns 7 through 12 are unweighted OLS estimates. The first

\footnotetext{
${ }^{20}$ Similar tests are performed by Ayres and Levitt (1998), when they look for effects of Lojack on crimes other than motor vehicle theft.
} 
column of each group controls for only state and year fixed effects. The second column adds region-by-year fixed effects, while the third column adds time-varying controls. The fourth column additionally includes an indicator variable for the year before the castle doctrine law was adopted; the fifth drops the leading indicator but adds controls for contemporaneous larceny and motor vehicle theft. Finally, the last column controls for state fixed effects, region-by-year fixed effects, time-varying controls, and state-specific linear time trends.

Estimates for larceny are close to zero and statistically insignificant across all specifications. Estimates of the effect on the log of the motor vehicle theft rate are more interesting. Results in columns 1 and 7 in which only state and year fixed effects are included provide suggestive evidence of increases in motor vehicle theft of 5 to 8 percent, the latter of which is significant at the 10 percent level. However, including region-by-year fixed effects in columns 2 and 8 causes the estimate to drop to zero or even turn negative, and both are statistically insignificant. This suggests that accounting for differences in regional trends in some way may be important in assessing the impact of castle doctrine laws.

\subsection{Deterrence}

We now examine whether strengthening self-defense law deters crime. We examine three types of crime: burglary, robbery, and aggravated assault. To the extent that criminals respond to the higher actual or perceived risk that victims will use lethal force to protect themselves, we would expect these crimes to decline after the adoption of castle 
doctrine.

Results are shown in Table 4, where the first 6 columns show estimates from an OLS regression weighted by state population, while the second 6 columns are from unweighted OLS regressions. Results in Column 1 in Panel A for burglary are similar to the finding for motor vehicle theft, in that estimates range from 6 to 8 percent and are statistically significant at the 5 percent level. Again, however, including region-by-year effects in columns 2 and 8 reduces the estimates considerably, and all are statistically indistinguishable from zero at the 5 percent level.

Importantly, there is little evidence of deterrence effects in any specification for any outcome: of the 36 estimates reported, none are negative and statistically significant at the 10 percent level. The estimates are sufficiently precise as to rule out large deterrence effects. For example, in our preferred specification in column 3, the lower bounds of estimates on burglary, robbery, and aggravated assault are -2.1 percent, -1.9 percent, and -2.5 percent. Put differently, our estimates and standard errors from column 3 indicate that if we were to perform this castle doctrine policy experiment many times, we would expect that 90 percent of the time we would find deterrence effects of less than 0.7 percent, 0.4 percent, and 0.5 percent for burglary, robbery, and aggravated assault, respectively. In short, these estimates provide strong evidence against the possibility that castle doctrine laws cause economically meaningful deterrence effects. Thus, while castle doctrine law may well have benefits to those protecting themselves in self-defense, there is no evidence that the law provides positive spillovers by deterring crime more generally. 


\subsection{Homicide}

We now turn to whether strengthening self-defense laws increases homicide. Given that the laws reduce the expected costs associated with using violence, economic theory would predict that there would be more of it. This could be driven by any of several possibilities. For example, the increase could be due to additional legally justified killings that are not reported that way by police. Perhaps more troubling is the possibility that under castle doctrine, conflicts or crimes that might not have otherwise turned deadly now do. For example, a criminal may not have intended to kill someone he was robbing until the victim attempted to use a weapon in self-defense. Alternatively, criminals may escalate violence in response to castle doctrine laws and cause in increase in homicide.

Results are shown in Panels A, B, and C of Table 5, which show population-weighted OLS estimates, unweighted OLS estimates, and unweighted estimates from a negative binomial model. Estimates from the negative binomial regression are interpreted in the same way as those from a log-linear OLS model. Results from the population-weighted shown in Panel A indicate that the homicide rate is increased by 8 to 10 percent; all 6 estimates are statistically significant at the 5 percent level, and 3 are significant at the 1 percent level. Estimates from unweighted OLS regressions shown in Panel B range from 5 to 9 percent, though all are measured imprecisely: t-statistics range from 0.6 to 1.5. Estimates in Panel $\mathrm{C}$ from a negative binomial model indicate castle doctrine leads to a 6 to 11 percent increase in homicide. All negative binomial estimates that include region-by-year fixed effects are significant at the 5 percent level, and that which does not (column 1) is significant at the 10 percent level. 
We have also done additional tests in order to ensure that we are making correct inferences about statistical significance. Toward that end, we do tests in the spirit of Bertrand et al. (2004), in which we randomly select 11-year panels from 1960 to 2004, and then randomly assign states to the treatment dates found in our data, without replacement. Thus, we assume that one state adopted castle doctrine on October $1^{\text {st }}$ of the $6^{\text {th }}$ year of the 11-year panel (just as Florida actually adopted in 2005, the $6^{\text {th }}$ year of our panel), and that 13 more states adopted in the $7^{\text {th }}$ year of the 11-year panel, etc. We generate distributions of estimates, and ask how often we reject the null hypothesis of no effect at the 5 percent level, as well as what proportion of the placebo estimates are larger than the actual estimated effect of (real) castle doctrine. The latter figure corresponds to a p-value and is similar to the method used in synthetic control methods (Abadie et al., 2010), as well as by Chetty, Looney, and Kroft (2009).

The resulting placebo distributions are shown in Figures 1, 2, and 3, and correspond to Table 5 results from column 2 of Panels A, B, and C, respectively. Results from population-weighted OLS placebo estimates suggest that robust clustered standard errors may be a bit too small: 11.9 percent of simulated estimates are significant at the 5 percent level. However, the estimate of 9.46 percent in column 2 ranks in the $95^{\text {th }}$ percentile of placebo estimates, which means only 5 percent of placebo estimates are larger than it is.

Results for unweighted OLS simulation results are also interesting. On the one hand, simulations corresponding to the specification in column 2 of Panel B in Table 5 suggest that clustered standard errors from unweighted OLS regressions are accurate: 6.3 
percent of the simulated estimates are significant at the 5 percent level. At the same time, however, the estimate of 8.1 percent shown in Table 5 corresponds to the $94.7^{\text {th }}$ percentile (see Figure 2), which would give it a p-value of 5.3 percent using the Abadie et al. (2010) approach to inference. This suggests that results in Panel B of Table 5 understate the degree of statistical significance.

Finally, simulations for the fixed effect negative binomial model corresponding to column 2 in Panel C indicate that 9.7 percent of placebo estimates are significant at the 5 percent level, while 15.6 percent are significant at the 10 percent level. As shown in Figure 3, the estimate of 7.3 percent in Table 5 ranks at the $95.4^{\text {th }}$ percentile, as fewer than 5 percent of placebo estimates were larger than the actual estimate in the simulations.

On the basis of these exercises, we conclude that it is unlikely that we would have obtained estimates of the magnitude and statistical significance shown in Panels A, B, and C of Table 5 due to chance.

We have also performed simulations to see if the homicide rates of these particular 21 states ever diverged in the way they did after adopting castle doctrine in the late 2000s. To do so, we created 40 panel data sets, each covering separate 11-year time periods between 1960 and 2009. In each 11-year panel, we assume that Florida adopts castle doctrine on October $1^{\text {st }}$ of the $6^{\text {th }}$ year, and that the 13 states that adopted in 2006 adopted in the $7^{\text {th }}$ year, etc. None of the 40 estimates corresponding to either the OLS population-weighted regressions or from the negative binomial regression were larger than those shown in column 2 of Table 5. In the case of the OLS unweighted regressions, only 1 of the 40 placebo estimates was larger than the actual estimate of 8.1 percent shown in 
Column 2, Panel B, of Table $5 .^{21}$ Thus, there is no evidence that the homicide rates in castle doctrine states show a general tendency to diverge from their regional counterparts: in the last 40 years they have almost never done so as much as they did immediately after they passed castle doctrine.

The relative increase in the homicide rate can be seen graphically as well. Figure 4 shows the log of homicide rate for the 13 states that adopted castle doctrine in 2006, as well as for the 29 states that did not extend castle doctrine from 2000 to $2010 .^{22}$ It shows that while the trends of the two groups track each other closely prior to castle doctrine, afterward homicides in adopting states increase relative to control states. Importantly, Figure 1 also gives us little reason to believe that even in the absence of castle doctrine, adopting states would have experienced an increase in homicides after 2005 relative to non-adopting states. ${ }^{23}$

Collectively, we view these findings as compelling evidence that castle doctrine increases homicide. However, we note that one downside of the homicide measure is that it could well include homicides that are justified under the new self-defense law, but are not reported separately as justifiable homicides. Thus, this increase may not be viewed by everyone as unambiguously bad. For example, the increase could be driven by

\footnotetext{
${ }^{21}$ The one larger estimate was 10.5 percent, and was from the 1975 to 1985 time period.

${ }^{22}$ It is more difficult to show a meaningful graph for the entire sample of adopting states, as they enacted castle doctrine in different years. Also, note that this graph does not rely on within-regional variation, unlike most of our specifications. Nevertheless, we think that showing results graphically for the largest subset of states that passed the law in the same year gives the reader a rough idea of the raw variation in the data.

${ }_{23}$ As shown in Figure 1, adopting states have homicide rates that are about 30 percent higher than non-adopting states. However, because we are using a difference-in-differences research design that conditions on year and state fixed effects, differences in levels is not a concern for identification. Instead, what would worry us is if the homicide rate in adopting states increased more than in non-adopting states even before treatment, as that would suggest that the groups might have continued to diverge afterward, regardless of castle doctrine. We see no evidence of that, which suggests that the relative increase seen after 2005 is caused by castle doctrine. Moreover, note that homicide estimates remained similar even after controlling for time-varying police and incarceration rates and other controls, including region-by-year fixed effects, and allowing for state-specific linear time trends.
} 
individuals protecting themselves from imminent harm by using lethal force. On the other hand, the increase could be driven by the escalation of violence in situations that otherwise would not have ended in serious injury for either party. Note, however, that the net increase cannot be driven by a one-to-one substitution of homicides of assailants for homicides of innocent victims. In contrast, in order for the entire increase in homicide to be driven by life-saving use of force, there would have to be at least some cases of multiple killed assailants by a would-be-killed victim.

Results in Panel D of Table 5 show results for murder, which excludes non-negligent manslaughter classifications that one might think would be used more often in self-defense killings not classified as justifiable homicides. Estimates indicate a similarly sized increase in murder, which suggests that police are largely classifying these additional homicides as murders.

Given the robustness of the estimates to various specifications, it is worth considering what one would have to believe for a confounding factor to cause the observed increase in murder/homicide, rather than castle doctrine. That is, one would have to believe that something else caused homicides to increase relative to non-adopting states immediately after castle doctrine was enacted, but not in the years prior to enactment. In addition, this confounder must have only caused a divergence in homicide rates in the late 2000s coincidental with the passage of castle doctrine, and not at any point in the 40 years prior. Furthermore, this confounder must cause an increase in homicides in castle doctrine states after adoption, but not cause a similar increase in states in the same region of the country that did not adopt castle doctrine at that time. Additionally, the confounder must 
cause adopting states to diverge from their own pre-adoption trend in homicide rate, coincidental with the enactment of castle doctrine. The confounder must also increase homicides in adopting states after adoption without causing proportionate increases in motor vehicle theft and larceny. Finally, the confounder must be uncorrelated with changes in the economic conditions, welfare generosity, and the rates of incarceration and policing in adopting states immediately following adoption. We are unable to think of any confounding factor that would fit this description, and thus we interpret the increase in homicides as the causal effect of castle doctrine.

\subsection{Homicide: Interpretation}

While it is clear that the increase in homicide is largely being classified by police as murder, it is possible that this represents a misclassification by police. Here we look directly for evidence of this and other interpretations. We start by assessing whether criminals appear to escalate violence in response to castle doctrine laws. For example, a rational criminal may respond to a real or perceived increase in the likelihood of encountering a victim willing to use lethal force by using a deadly weapon himself. Thus, we examine whether castle doctrine increases felony-type and suspected felony-type murders, which appeared to be committed during a felony. Results are shown in Panel A of Table 6. The estimate from column 1, which controls only for state and year fixed effects, is 10 percent and is statistically indistinguishable from zero. Estimates from specifications including region-by-year fixed effects are more suggestive of a criminal escalation effect: estimates in columns 2 through 5 are around 20 percent and are 
statistically significant at the 10 percent level, though we note the estimate goes to zero when allowing for state-specific time trends in column 6 . We also examine whether criminals are more likely to use guns during robberies. ${ }^{24}$ Results in Panel B of Table 6 indicate that there is little evidence of this type of escalation, at least once one compares states to others in their same region. ${ }^{25}$ In short, while we find some suggestive evidence of escalation by criminals, the evidence is far from conclusive.

Finally, we turn to evidence on whether the laws increase the reported number of justifiable homicides. The problem with these data is that justifiable homicides are believed to be underreported: Kleck (1988) estimates that only one-fifth of legally justified homicides by civilians are reported. However, even though the level of justifiable homicides may be underreported, relative changes in justifiable homicide may still be informative. As a result, we focus on examining the relative increase in reported justifiable homicide, and then estimate how many additional legally justified homicides there really are by scaling the pre-castle doctrine figure by estimates of underreporting.

Results are shown in Panels C, D, and E of Table 6. Panel C shows estimates from population-weighted regressions in which the number of justifiable homicides is the dependent variable. Results range from 1 to 9 additional justifiable homicides, which is relative to a baseline population-weighted average of 10.0 justifiable homicides per state in the year prior to castle doctrine enactment. Thus, the estimate when controlling for only

\footnotetext{
${ }^{24}$ We also look at the proportion of assaults in which a gun was used and find no evidence of an increase, though the baseline rate is small (3 percent). We also note that examining these ratios as outcome variables could be problematic if the laws were found to reduce robbery or aggravated assault. However, as we show in Table 4 there is no effect on robberies or aggravated assaults.

${ }^{25}$ It is difficult to think of how using other FBI classifications could help answer this question. For example, the FBI classifies some non-felony-type homicides as having originated in an argument. It is difficult to know, however, whether the argument would have resulted in serious injury to the killer, had that person not used lethal force, or if the argument escalated from, say, a fistfight into a homicide. Yet most would agree that the latter is more disturbing than the former.
} 
state and year fixed effects suggests that there is a statistically significant 90 percent increase in justifiable homicide as a result of the law, though we note that the estimate in our preferred specification in column 3 is 4.6, is statistically significant at the 10 percent level, and represents a 46 percent increase. ${ }^{26}$

Panel D shows estimates from unweighted regressions of similar form. Results range from 1 to 4.3 additional justifiable homicides per state per year as a result of castle doctrine. The estimate in our preferred specification is 3.4, is statistically significant at the 5 percent level, and represents a 70 percent increase over the pre-castle doctrine average of 4.9 justifiable homicides per year.

Panel E reports estimates from a negative binomial model. Estimates range from an insignificant 22 percent increase to a significant 57 percent increase in column 1, which does not control for region-by-year fixed effects.

Using these estimates, we now turn to assessing whether the relative increases observed in Table 6 can explain the entire increase in homicide, given estimates of the degree of underreporting of legally justified homicide. The largest estimated relative increase from a specification in Table 6 that controls for region-by-year fixed effects is 70 percent, which is relative to a baseline total of 103 justifiable homicides across the 21 states in the year prior to castle doctrine enactment. We assume that i) police departments are not less likely to report an otherwise-identical homicide as justifiable after castle doctrine, and ii) the relative increase in legally justified homicide due to castle doctrine is no lower for reporting agencies than for non-reporting agencies. We view the first of these

\footnotetext{
${ }^{26}$ In contrast, we find no evidence of an increase in justifiable homicide by police, consistent with the identifying assumption. Results are shown in Table A2 of the web appendix.
} 
assumptions as likely to hold, and the second as reasonable, though we emphasize that they are in fact assumptions. Combining these assumptions with our estimates in Table 5 suggests that the true castle-doctrine-induced relative increase in legally justified homicide across the 21 states should be no larger than 70 percent.

Kleck (1988) reports that approximately one-fifth of legally justified homicides are reported correctly, while the others are classified as homicides. Given the 103 reported pre-castle doctrine justifiable homicides, that suggests that the true figure is 515 . A 70 percent increase means that castle doctrine causes an additional 361 legally justified homicides, of which 289 (80 percent) would be (mis)reported as homicides. Recall that estimates from Table 5 indicate that castle doctrine causes approximately an 8 percent increase in homicide, which translates to an additional 611 homicides given the 7,632 pre-castle doctrine homicides. Thus, under these assumptions, our best guess is that around half of the additional homicides caused by castle doctrine were legally justified.

Of course, different assumptions yield different conclusions. For example, assuming that only 10 percent of legally justified homicides are reported correctly, along with a 70 percent relative increase and the second assumption outlined above, would suggest that all of the additional homicides were legally justified.

In summary, we find no evidence that strengthening self-defense law deters crime. On the other hand, we find that a primary consequence of castle doctrine laws is to increase homicide by a statistically and economically significant 7 to 10 percent. Relative increases in justifiable homicide along with Kleck's (1988) estimate of the degree of underreporting suggest that it is unlikely, but not impossible, for the increase in homicides 
to consist entirely of legally justified homicides. We emphasize, however, that one's conclusion on that issue depends on assumptions about the nature and degree of underreporting of legally justified homicides.

\section{Conclusion}

In recent years, more than 20 states have strengthened their self-defense laws by adopting castle doctrine laws. These statutes widen the scope for the justified use of lethal force in self-defense by stating the circumstances under which self-defense is justified and removing the duty to retreat from a list of protected places outside the home. In addition, in some cases they establish a presumption of reasonableness and remove civil liability. Thus, these laws could hypothetically deter crime or, alternatively, increase homicide.

Results presented indicate that castle doctrine law does not deter crime. Furthermore, our estimates are sufficiently precise as to rule out moderate-sized deterrence effects. Thus, while our view is that it is a priori reasonable to expect that strengthening self-defense law would deter crime, we find this is not the case.

More significantly, results indicate that castle doctrine laws increase total homicides by around 8 percent. Put differently, the laws induce an additional 600 homicides per year across the 21 states in our sample that enacted castle doctrine laws. This finding is robust to a wide set of difference-in-differences specifications, including region-by-year fixed effects, state-specific linear time trends, and controls for time-varying factors such as economic conditions, state welfare spending, and policing and incarceration rates. These findings provide evidence that lowering the expected cost of lethal force 
causes there to be more of it.

A critical question is whether all of the additional homicides that occur were legally justified. Using results on the effect of the laws on justifiable homicide, along with assumptions about the degree to which justifiable homicides are underreported, we report back-of-the-envelope calculations that make it difficult to explain the entire increase in homicide with an increase in legally justified homicide. Our view is that this provides suggestive evidence that at least some of the additional homicides were not legally justified, though we emphasize that conclusions on this issue depend on assumptions regarding the degree and nature of the underreporting of justifiable homicide by police to the FBI.

With respect to policy, our findings suggest that an informed debate over these laws will weigh the increased protections given to victims against the net increase in violent deaths that result. More broadly, our findings indicate that incentives and expected costs matter when it comes to the decision of whether to use lethal force. 


\section{References}

Abadie, Alberto, Alexis Diamond, and Jens Hainmueller. 2010. “Synthetic Control Methods for Comparative Case Studies: Estimating the Effect of California's Tobacco Control Program.” Journal of the American Statistical Association, 105: 493-505.

Alvarez, Lizette. “A Florida Law Gets Scrutiny After a Teenager’s Killing.” New York Times, March 20, 2012. Last accessed on March 29, 2012 at http://www.nytimes.com/2012/03/21/us/justice-department-opens-inquiry-in-killin g-of-trayvon-martin.html?scp=26\&sq=trayvon\%20martin\&st=cse.

American Community Survey. 2000 - 2010. United States Census Bureau.

Ayres, Ian, and Steven Levitt. 1998. "Measuring Positive Externalities from Unobservable Victim Precaution: An Empirical Analysis of Lojack.” Quarterly Journal of Economics, 113 (1): 43-77.

Becker, Gary. 1968. “Crime and Punishment: An Economic Approach,” Journal of Political Economy, 76 (2): 169-217.

Bertrand, Marianne, Esther Duflo, and Sendhil Mullainathan. 2004. "How Much should We Trust Differences-in-Differences Estimates?” Quarterly Journal of Economics, 119(1): 249-275.

Blumenthal, Ralph. "Shootings Test Limits of New Self-Defense Law," New York Times December 13, 2007. Last accessed on March 29, 2012 at http://www.nytimes.com/2007/12/13/us/13texas.html.

Bronars, Stephen, and John R. Lott, Jr. 1998. "Criminal Deterrence, Geographic Spillovers, and the Right to Carry Concealed Handguns,” American Economic Review, 88 (2): 475-479.

Cameron, A. Colin, and Pravin K. Trivedi. 2010. Microeconometrics Using Stata. Stata Press: College Station, Texas.

Chetty, Raj, Adam Looney and Kory Kroft. 2009. "Salience and Taxation: theory and Evidence,” American Economic Review, 99(4): 1145-1177.

Dezhbakhsh, Hashem, and Paul H. Rubin. 1998. "Lives Saved or Lives Lost? The Effects of Concealed-Handgun Laws on Crime,” American Economic Review, 88 (2): 468-474. 
Di Tella, Rafael, and Ernesto Schargrodsky. 2004. "Do Police Reduce Crime? Estimates Using the Allocation of Police Forces After a Terrorist Attack,” American Economic Review 94 (1): 115-133.

Donohue, John J., and Justin Wolfers. 2009. "Estimating the Impact of the Death Penalty on Murder,” American Law and Economics Review, 11 (2): 249-309.

Ehrlich, Isaac. 1973. "Participation in Illegitimate Activities: A Theoretical and Empirical Investigation," Journal of Political Economy, 81 (3): 521.

Goode, Erica. 2012. “N.R.A.’s Influence Seen in Expansion of Self-Defense Laws,” New York Times, April 12. Last accessed on May 29 at http://www.nytimes.com /2012/04/13/us/nra-campaign-leads-to-expanded-self-defense-laws.html ?pagewanted=all.

Kleck, Gary. 1988. " “Crime Control through the Private Use of Armed Force”. Social Problems, 35(1): 1-21.

Lott, John R. Jr. 2010. More Guns, Less Crime. University of Chicago Press.

Lott, John R. Jr., and David B. Mustard. 1997. "Crime Deterrence, and the Right-to-Carry Concealed Handguns,” Journal of Legal Studies, 26 (1): 1-68.

Ludwig, Jens. 1998. "Concealed-Gun-Carrying Laws and Violent Crime: Evidence from State Panel Data." International Review of Law and Economics, 18 (3): 239-254.

McClellan, Chandler B., and Erdal Tekin. 2012. "Stand Your Ground Laws and Homicides.” NBER Working Paper 18187.

O’Flaherty, Brendan, and Rajiv Sethi. 2010. Homicide in Black and White. Journal of Urban Economics, 68: 215-230.

Saad, Lydia. 2011. “Self-Reported Gun Ownership in U.S. Is Highest Since 1993.” Last accessed on May 16, 2012 at http://www.gallup.com/poll/150353/self-reported-gun -ownership-highest-1993.aspx

Texas Department of Public Safety. 2006. “Active License Holders and Certified Instructors.” Last accessed on May 16, 2012 at http://www.txdps.state.tx.us/ administration/crime_records/chl/PDF/ActLicAndInstr/ ActiveLicandInstr2006.pdf.

Texas Department of State Health Services. 2006. “Texas Population Data Detailed Data in Excel Format.” $\quad$ Last accessed on May 16, 2012 at http://www.dshs.state.tx.us/chs/popdat/detailX.shtm. 
Uniform Crime Reporting Handbook. 2004. Federal Bureau of Investigation.

Last accessed on April 30, 2012 at

http://www2.fbi.gov/ucr/handbook/ucrhandbook04.pdf.

Uniform Crime Reports. $\quad 2000$ - 2010. Federal Bureau of Investigation.

Bureau of Justice Statistics Bulletin. 2000-2010. United States Bureau of Justice Statistics.

United States Census. 2000 - 2010. State Government Finances. Last accessed on June 24, 2012 at http://www.census.gov//govs/state/historical_data_2000.html.

Vilos, James. D., and Evan John Vilos. 2010. Self-Defense Laws of All 50 States. Guns West Publishing. 
Figure 1: Empirical Distribution of Placebo Homicide Estimates: Population-Weighted OLS

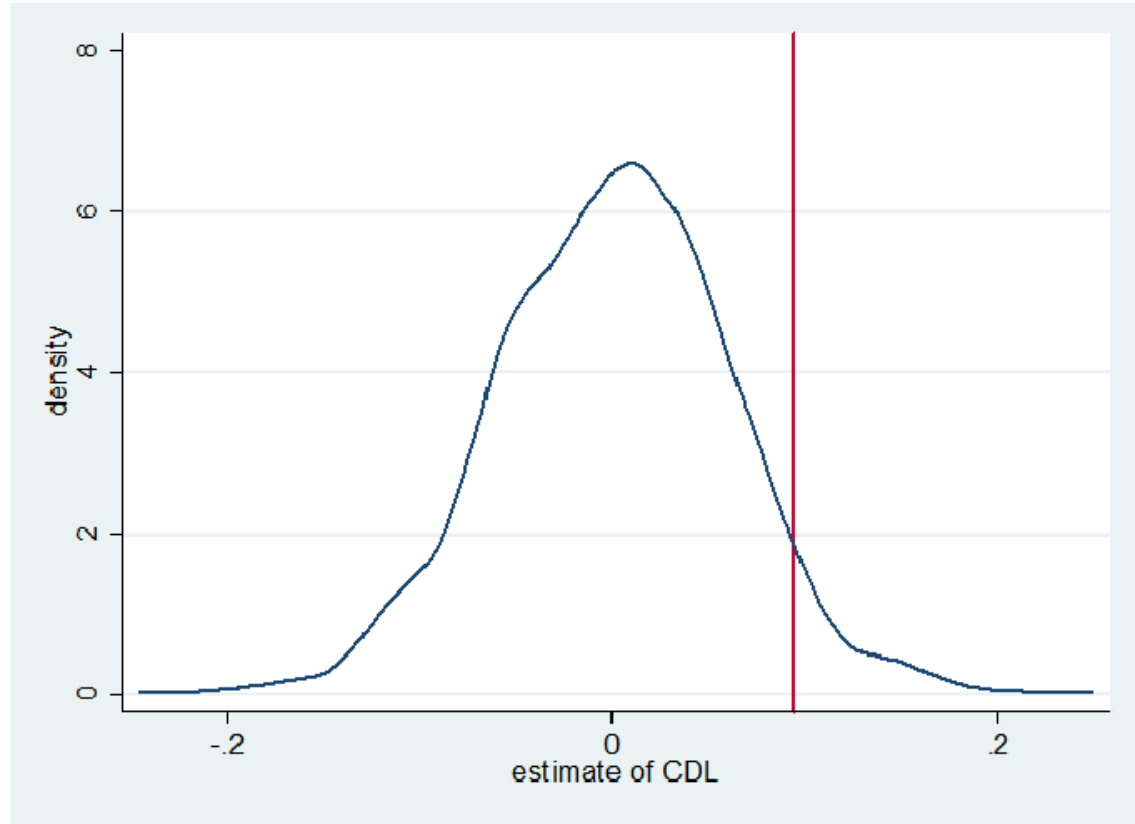

Notes: The vertical line represents the actual estimated effect of castle doctrine on log homicide of 0.0946, as shown in Column 2, Panel A, Table 5. A total of 5.0 percent of placebo estimates lie to the right of this estimate.

Figure 2: Empirical Distribution of Placebo Homicide Estimates: Unweighted OLS

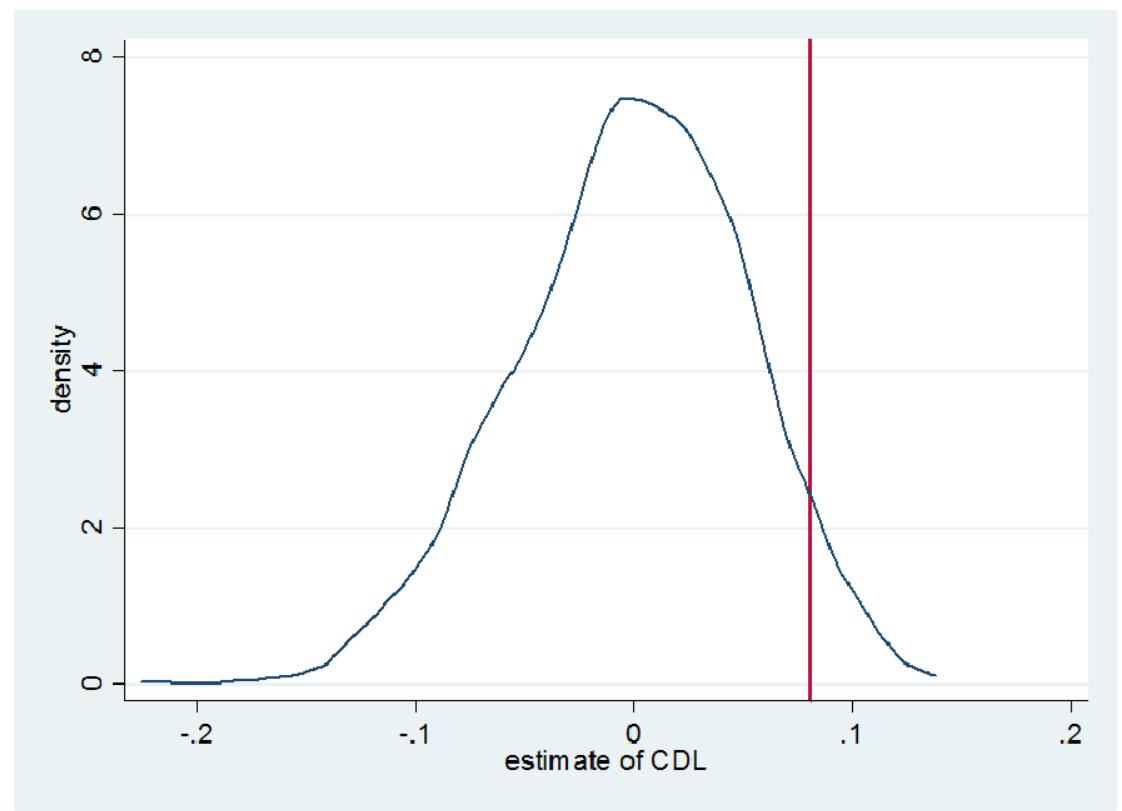

Notes: The vertical line represents the actual estimated effect of castle doctrine on log homicide of 0.0811, as shown in Column 2, Panel B, Table 5. A total of 5.3 percent of placebo estimates lie to the right of this estimate. 
Figure 3: Empirical Distribution of Placebo Homicide Estimates: Negative Binomial

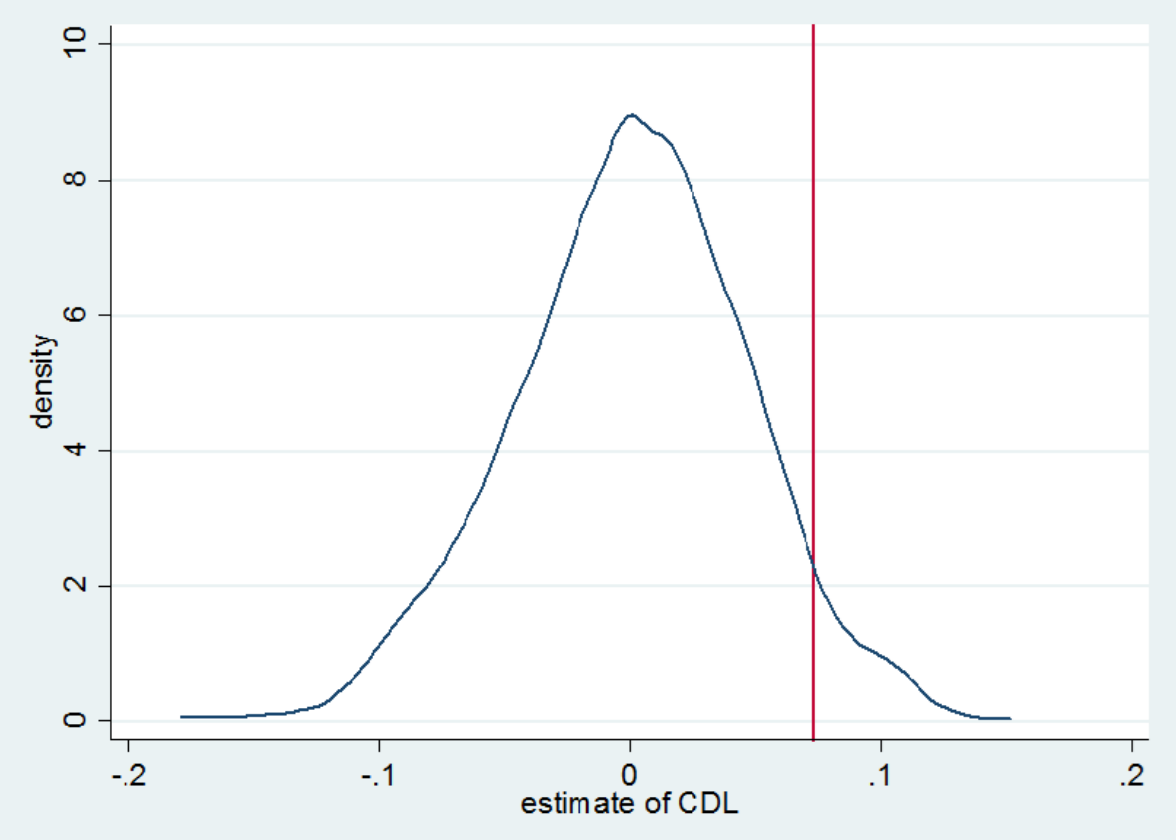

Notes: The vertical line represents the actual estimated effect of castle doctrine on homicide of 0.0734, as shown in Column 2, Panel C, Table 5. A total of 4.6 percent of placebo estimates lie to the right of this estimate.

Figure 4: Log Homicide Rate for the 13 States That Enacted Castle Doctrine in 2006 Compared to States That Did Not Enact Castle Doctrine from 2000 to 2010

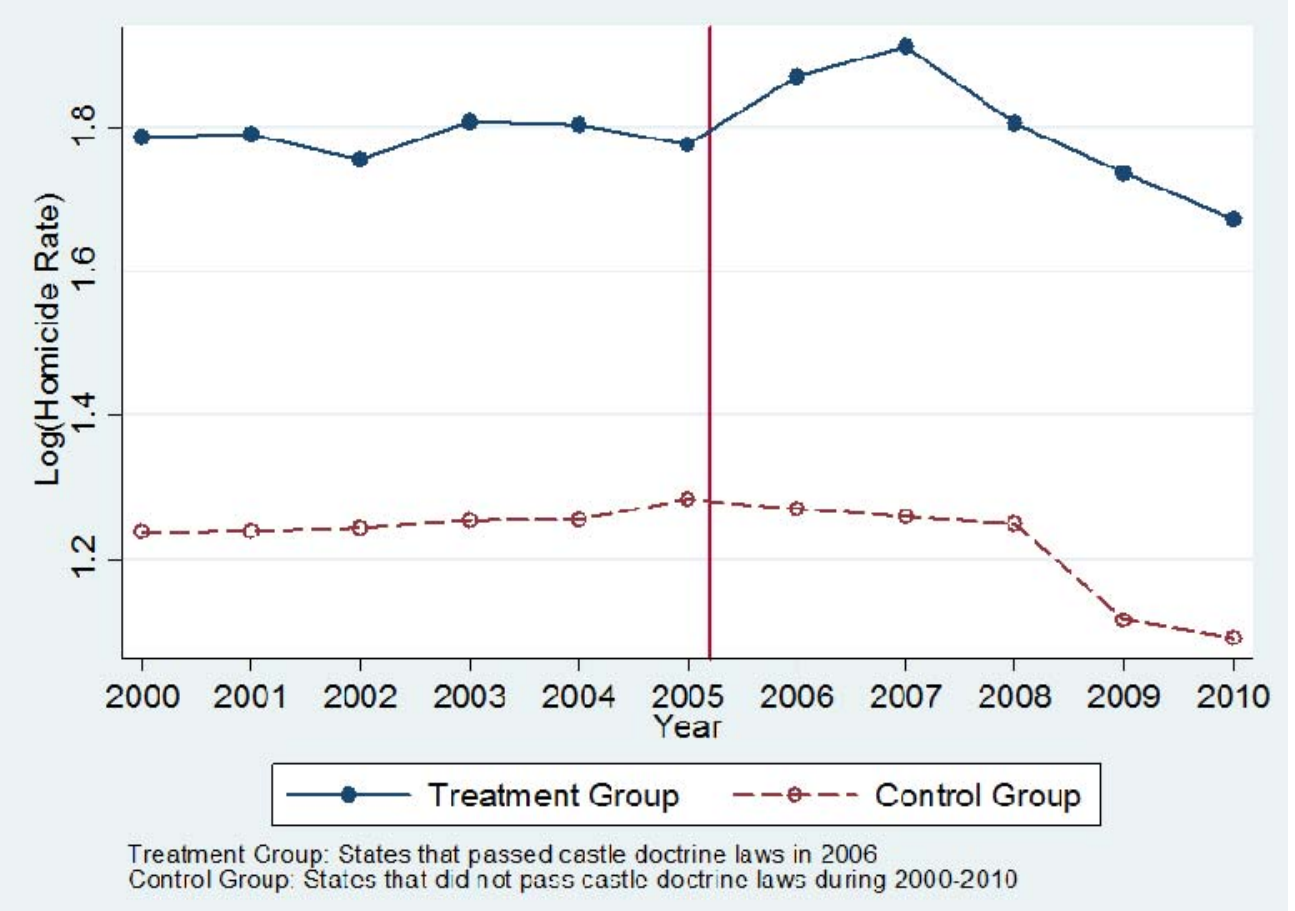


Table 1: States that Extended Castle Doctrine Between 2000 and 2010

\begin{tabular}{|c|c|c|c|c|c|}
\hline State & $\begin{array}{c}\text { Effective } \\
\text { Year }\end{array}$ & $\begin{array}{l}\text { Removes duty to } \\
\text { retreat somewhere } \\
\text { outside home }\end{array}$ & $\begin{array}{c}\text { Removes duty to retreat } \\
\text { in any place one has a } \\
\text { legal right to be }\end{array}$ & $\begin{array}{l}\text { Presumption of } \\
\text { reasonable fear }\end{array}$ & $\begin{array}{c}\text { Removes } \\
\text { civil } \\
\text { liability }\end{array}$ \\
\hline Alabama & 2006 & Yes & Yes & No & Yes \\
\hline Alaska & 2006 & Yes & No & Yes & Yes \\
\hline Arizona & 2006 & Yes & Yes & Yes & Yes \\
\hline Florida & 2005 & Yes & Yes & Yes & Yes \\
\hline Georgia & 2006 & Yes & Yes & No & Yes \\
\hline Indiana & 2006 & Yes & Yes & No & Yes \\
\hline Kansas & 2006 & Yes & Yes & No & Yes \\
\hline Kentucky & 2006 & Yes & Yes & Yes & Yes \\
\hline Louisiana & 2006 & Yes & Yes & Yes & Yes \\
\hline Michigan & 2006 & Yes & Yes & No & Yes \\
\hline Mississippi & 2006 & Yes & Yes & Yes & Yes \\
\hline Missouri & 2007 & Yes & No & No & Yes \\
\hline Montana & 2009 & Yes & Yes & Yes & No \\
\hline North Dakota & 2007 & Yes & No & Yes & Yes \\
\hline Ohio & 2008 & Yes & No & Yes & Yes \\
\hline Oklahoma & 2006 & Yes & Yes & Yes & Yes \\
\hline South Carolina & 2006 & Yes & Yes & Yes & Yes \\
\hline South Dakota & 2006 & Yes & Yes & No & No \\
\hline Tennessee & 2007 & Yes & Yes & Yes & Yes \\
\hline Texas & 2007 & Yes & Yes & Yes & Yes \\
\hline West Virginia & 2008 & Yes & Yes & No & No \\
\hline
\end{tabular}


Table 2: Descriptive Statistics

\begin{tabular}{|c|c|c|}
\hline & Mean (Unweighted) & $\begin{array}{c}\text { Mean (Weighted by } \\
\text { Population) }\end{array}$ \\
\hline \multicolumn{3}{|l|}{ Dependent Variables } \\
\hline \multirow[t]{2}{*}{ Homicides per 100,000 Population } & 4.8 & 5.5 \\
\hline & $(2.5)$ & $(1.9)$ \\
\hline \multirow[t]{2}{*}{ Justifiable Homicide by Private Citizens (count) } & 5.1 & 11.8 \\
\hline & $(8.2)$ & $(12.9)$ \\
\hline \multirow[t]{2}{*}{ Justifiable Homicide by Police (count) } & 8.0 & 23.4 \\
\hline & $(16.9)$ & $(34.3)$ \\
\hline \multirow[t]{2}{*}{ Robberies per 100,000 Population } & 107.2 & 143.1 \\
\hline & $(59.6)$ & $(47.5)$ \\
\hline \multirow[t]{2}{*}{ Aggravated Assault per 100,000 Population } & 267 & 296 \\
\hline & $(131)$ & $(114)$ \\
\hline \multirow[t]{2}{*}{ Burglary per 100,000 Population } & 710 & 744 \\
\hline & $(240)$ & $(235)$ \\
\hline \multirow[t]{2}{*}{ Larceny per 100,000 Population } & 2,334 & 2,328 \\
\hline & $(533)$ & $(532)$ \\
\hline \multirow[t]{2}{*}{ Motor Theft per 100,000 Population } & 331 & 381 \\
\hline & $(178)$ & $(174)$ \\
\hline \multirow[t]{2}{*}{ Proportion of Robberies in Which a Gun Was Used } & 0.35 & 0.37 \\
\hline & $(0.13)$ & $(0.13)$ \\
\hline \multicolumn{3}{|l|}{ Control Variables } \\
\hline \multirow[t]{2}{*}{ Police per 100,000 residents } & 315 & 336 \\
\hline & (65) & $(66)$ \\
\hline \multirow[t]{2}{*}{ Unemployment Rate (\%) } & 5.49 & 5.93 \\
\hline & $(1.99)$ & $(2.10)$ \\
\hline \multirow[t]{2}{*}{ Poverty Rate (\%) } & 12.4 & 12.9 \\
\hline & $(3.0)$ & $(2.6)$ \\
\hline \multirow[t]{2}{*}{ Median Household Income (\$) } & 51,648 & 52,146 \\
\hline & $(7873)$ & $(6895)$ \\
\hline \multirow[t]{2}{*}{ Prisoners per 100,000 residents } & 439 & 461 \\
\hline & $(169)$ & $(150)$ \\
\hline \multirow[t]{2}{*}{ Government spending (assistance and subsidies) per capita } & 125 & 110 \\
\hline & $(56)$ & $(48)$ \\
\hline \multirow[t]{2}{*}{ Government spending (public welfare) per capita } & 1,319 & 1,344 \\
\hline & $(391)$ & $(409)$ \\
\hline \multirow[t]{2}{*}{$\%$ Black Male Aged 15-24 } & 2.60 & 0.97 \\
\hline & $(4.61)$ & $(2.11)$ \\
\hline \multirow[t]{2}{*}{$\%$ White Male Aged 15-24 } & 10.77 & 4.36 \\
\hline & $(17.70)$ & (7.69) \\
\hline \multirow[t]{2}{*}{$\%$ Black Male Aged 25-44 } & 4.32 & 1.61 \\
\hline & (7.71) & $(3.53)$ \\
\hline \multirow[t]{2}{*}{$\%$ White Male Aged 25-44 } & 21.97 & 8.88 \\
\hline & $(36.40)$ & $(15.90)$ \\
\hline
\end{tabular}

Notes: Each cell contains the mean with the standard deviation in parentheses. All variables have 550 observations except for the proportion of assaults in which a gun was used (544) and the proportion of robberies in which a gun was used (544). 
Table 3: Falsification Tests: The Effect of Castle Doctrine on Larceny and Motor Vehicle Theft

\begin{tabular}{|c|c|c|c|c|c|c|c|c|c|c|c|c|}
\hline & \multicolumn{6}{|c|}{ OLS - Weighted by State Population } & \multicolumn{6}{|c|}{ OLS - Unweighted } \\
\hline & 1 & 2 & 3 & 4 & 5 & 6 & 7 & 8 & 9 & 10 & 11 & 12 \\
\hline Panel A: Larceny & \multicolumn{6}{|c|}{ Log (Larceny Rate) } & \multicolumn{6}{|c|}{ Log (Larceny Rate) } \\
\hline Castle Doctrine Law & $\begin{array}{l}0.00300 \\
(0.0161)\end{array}$ & $\begin{array}{r}-0.00660 \\
(0.0147)\end{array}$ & $\begin{array}{r}-0.00910 \\
(0.0139)\end{array}$ & $\begin{array}{l}-0.0149 \\
(0.0156)\end{array}$ & $\begin{array}{l}-0.00401 \\
(0.0128)\end{array}$ & $\begin{array}{l}-0.00284 \\
(0.0180)\end{array}$ & $\begin{array}{l}0.00745 \\
(0.0227)\end{array}$ & $\begin{array}{l}0.00145 \\
(0.0205)\end{array}$ & $\begin{array}{r}-0.00188 \\
(0.0210)\end{array}$ & $\begin{array}{r}-0.00445 \\
(0.0226)\end{array}$ & $\begin{array}{r}-0.00361 \\
(0.0201)\end{array}$ & $\begin{array}{l}-0.0137 \\
(0.0228)\end{array}$ \\
\hline $\begin{array}{l}\text { One Year Before Adoption of } \\
\text { Castle Doctrine Law }\end{array}$ & \multicolumn{6}{|c|}{$-0.0197^{* *}$} & \multicolumn{6}{|c|}{-0.0103} \\
\hline Observation & 550 & 550 & 550 & 550 & 550 & 550 & 550 & 550 & 550 & 550 & 550 & 550 \\
\hline Panel B: Motor Vehicle Theft & \multicolumn{6}{|c|}{ Log (Motor Vehicle Theft Rate) } & \multicolumn{6}{|c|}{ Log (Motor Vehicle Theft Rate) } \\
\hline Castle Doctrine Law & $\begin{array}{c}0.0517 \\
(0.0563)\end{array}$ & $\begin{array}{l}-0.0389 \\
(0.0448)\end{array}$ & $\begin{array}{l}-0.0252 \\
(0.0396)\end{array}$ & $\begin{array}{l}-0.0320 \\
(0.0451)\end{array}$ & $\begin{array}{l}-0.0165 \\
(0.0354)\end{array}$ & $\begin{array}{l}-0.00708 \\
(0.0372)\end{array}$ & $\begin{array}{l}0.0767^{*} \\
(0.0413)\end{array}$ & $\begin{array}{c}0.0138 \\
(0.0444)\end{array}$ & $\begin{array}{l}0.00814 \\
(0.0407)\end{array}$ & $\begin{array}{l}0.00775 \\
(0.0462)\end{array}$ & $\begin{array}{l}0.00977 \\
(0.0391)\end{array}$ & $\begin{array}{l}-0.00373 \\
(0.0361)\end{array}$ \\
\hline $\begin{array}{l}\text { One Year Before Adoption of } \\
\text { Castle Doctrine Law }\end{array}$ & & & & $\begin{array}{l}-0.0231 \\
(0.0233)\end{array}$ & & & & & & $\begin{array}{r}-0.00155 \\
(0.0287)\end{array}$ & & \\
\hline Observation & 550 & 550 & 550 & 550 & 550 & 550 & 550 & 550 & 550 & 550 & 550 & 550 \\
\hline State and Year Fixed Effects & Yes & Yes & Yes & Yes & Yes & Yes & Yes & Yes & Yes & Yes & Yes & Yes \\
\hline Region-by-Year Fixed Effects & & Yes & Yes & Yes & Yes & Yes & & Yes & Yes & Yes & Yes & Yes \\
\hline Time-Varying Controls & & & Yes & Yes & Yes & Yes & & & Yes & Yes & Yes & Yes \\
\hline Controls for Larceny or Motor & & & & & Yes & & & & & & Yes & \\
\hline State-Specific Linear Time Tre & & & & & & Yes & & & & & & Yes \\
\hline
\end{tabular}

Notes: Each column in each panel represents a separate regression. The unit of observation is state-year. Robust standard errors are clustered at the state

level. Time-varying controls include policing and incarceration rates, welfare and public assistance spending, median income, poverty rate, unemployment rate, and demographics.

* Significant at the $10 \%$ level

** Significant at the $5 \%$ level

$* * *$ Significant at the $1 \%$ level 
Table 4: The Deterrence Effects of Castle Doctrine: Burglary, Robbery, and Aggravated Assault

\begin{tabular}{|c|c|c|c|c|c|c|c|c|c|c|c|c|}
\hline & \multicolumn{6}{|c|}{ OLS - Weighted by State Population } & \multicolumn{6}{|c|}{ OLS - Unweighted } \\
\hline & 1 & 2 & 3 & 4 & 5 & 6 & 7 & 8 & 9 & 10 & 11 & 12 \\
\hline Panel A: Burglary & \multicolumn{6}{|c|}{ Log (Burglary Rate) } & \multicolumn{6}{|c|}{ Log (Burglary Rate) } \\
\hline Castle Doctrine Law & $\begin{array}{l}0.0780^{* * *} \\
(0.0255)\end{array}$ & $\begin{array}{c}0.0290 \\
(0.0236)\end{array}$ & $\begin{array}{c}0.0223 \\
(0.0223)\end{array}$ & $\begin{array}{c}0.0164 \\
(0.0247)\end{array}$ & $\begin{array}{l}0.0327^{\star} \\
(0.0165)\end{array}$ & $\begin{array}{c}0.0237 \\
(0.0207)\end{array}$ & $\begin{array}{l}0.0572 * * \\
(0.0272)\end{array}$ & $\begin{array}{l}0.00961 \\
(0.0291)\end{array}$ & $\begin{array}{l}0.00663 \\
(0.0268)\end{array}$ & $\begin{array}{l}0.00277 \\
(0.0304)\end{array}$ & $\begin{array}{l}0.00683 \\
(0.0222)\end{array}$ & $\begin{array}{r}0.0207 \\
(0.0259)\end{array}$ \\
\hline $\begin{array}{l}\text { One Year Before Adoption of } \\
\text { Castle Doctrine Law }\end{array}$ & & & & $\begin{array}{l}-0.0201 \\
(0.0139)\end{array}$ & & & & & & $\begin{array}{l}-0.0154 \\
(0.0214)\end{array}$ & & \\
\hline Panel B: Robbery & \multicolumn{6}{|c|}{ Log (Robbery Rate) } & \multicolumn{6}{|c|}{ Log (Robbery Rate) } \\
\hline Castle Doctrine Law & $\begin{array}{c}0.0408 \\
(0.0254)\end{array}$ & $\begin{array}{c}0.0344 \\
(0.0224)\end{array}$ & $\begin{array}{c}0.0262 \\
(0.0229)\end{array}$ & $\begin{array}{c}0.0216 \\
(0.0246)\end{array}$ & $\begin{array}{l}0.0376^{* *} \\
(0.0181)\end{array}$ & $\begin{array}{l}0.0515^{\star} \\
(0.0274)\end{array}$ & $\begin{array}{c}0.0448 \\
(0.0331)\end{array}$ & $\begin{array}{c}0.0320 \\
(0.0421)\end{array}$ & $\begin{array}{l}0.00839 \\
(0.0387)\end{array}$ & $\begin{array}{l}0.00552 \\
(0.0437)\end{array}$ & $\begin{array}{l}0.00874 \\
(0.0339)\end{array}$ & $\begin{array}{c}0.0267 \\
(0.0299)\end{array}$ \\
\hline $\begin{array}{l}\text { One Year Before Adoption of } \\
\text { Castle Doctrine Law }\end{array}$ & & & & $\begin{array}{l}-0.0156 \\
(0.0167) \\
\end{array}$ & & & & & & $\begin{array}{l}-0.0115 \\
(0.0283) \\
\end{array}$ & & \\
\hline Panel C: Aggravated Assault & \multicolumn{6}{|c|}{ Log (Aggravated Assault Rate) } & \multicolumn{6}{|c|}{ Log (Aggravated Assault Rate) } \\
\hline Castle Doctrine Law & $\begin{array}{c}0.0434 \\
(0.0387)\end{array}$ & $\begin{array}{c}0.0397 \\
(0.0407)\end{array}$ & $\begin{array}{c}0.0372 \\
(0.0319)\end{array}$ & $\begin{array}{c}0.0362 \\
(0.0349)\end{array}$ & $\begin{array}{c}0.0424 \\
(0.0291)\end{array}$ & $\begin{array}{c}0.0414 \\
(0.0285)\end{array}$ & $\begin{array}{c}0.0555 \\
(0.0604)\end{array}$ & $\begin{array}{c}0.0698 \\
(0.0630)\end{array}$ & $\begin{array}{c}0.0343 \\
(0.0433)\end{array}$ & $\begin{array}{c}0.0305 \\
(0.0478)\end{array}$ & $\begin{array}{c}0.0341 \\
(0.0405)\end{array}$ & $\begin{array}{c}0.0317 \\
(0.0380)\end{array}$ \\
\hline $\begin{array}{l}\text { One Year Before Adoption of } \\
\text { Castle Doctrine Law }\end{array}$ & & & & $\begin{array}{r}-0.00343 \\
(0.0161) \\
\end{array}$ & & & & & & $\begin{array}{l}-0.0150 \\
(0.0251) \\
\end{array}$ & & \\
\hline Observations & 550 & 550 & 550 & 550 & 550 & 550 & 550 & 550 & 550 & 550 & 550 & 550 \\
\hline State and Year Fixed Effects & Yes & Yes & Yes & Yes & Yes & Yes & Yes & Yes & Yes & Yes & Yes & Yes \\
\hline Region-by-Year Fixed Effects & & Yes & Yes & Yes & Yes & Yes & & Yes & Yes & Yes & Yes & Yes \\
\hline Time-Varying Controls & & & Yes & Yes & Yes & Yes & & & Yes & Yes & Yes & Yes \\
\hline Contemporaneous Crime Rates & & & & & Yes & & & & & & Yes & \\
\hline State-Specific Linear Time Trends & & & & & & Yes & & & & & & Yes \\
\hline
\end{tabular}

Notes: Each column in each panel represents a separate regression. The unit of observation is state-year. Robust standard errors are clustered at the state level. Time-varying controls include policing and incarceration rates, welfare and public assistance spending, median income, poverty rate, unemployment rate, and demographics. Contemporaneous crime rates include larceny and motor vehicle theft rates.

* Significant at the $10 \%$ level

** Significant at the 5\% level

*** Significant at the $1 \%$ level 
Table 5: The Effect of Castle Doctrine on Homicide

\begin{tabular}{|c|c|c|c|c|c|c|}
\hline \multirow{2}{*}{\multicolumn{7}{|c|}{ Panel A: Log Homicide Rate (OLS - Weighted) }} \\
\hline & & & & & & \\
\hline Castle Doctrine Law & $\begin{array}{l}0.0801^{* *} \\
(0.0342)\end{array}$ & $\begin{array}{l}0.0946^{* * *} \\
(0.0279)\end{array}$ & $\begin{array}{l}0.0937^{* * *} \\
(0.0290)\end{array}$ & $\begin{array}{l}0.0875^{* *} \\
(0.0337)\end{array}$ & $\begin{array}{l}0.0985^{* * *} \\
(0.0299)\end{array}$ & $\begin{array}{l}0.100^{* *} \\
(0.0388)\end{array}$ \\
\hline $\begin{array}{l}\text { One Year Before Adoption of Castle Doctrine } \\
\text { Law }\end{array}$ & & & & $\begin{array}{l}-0.0212 \\
(0.0246)\end{array}$ & & \\
\hline Observations & 550 & 550 & 550 & 550 & 550 & 550 \\
\hline \multicolumn{7}{|l|}{ Panel B: Log Homicide Rate (OLS - Unweighted) } \\
\hline Castle Doctrine Law & $\begin{array}{c}0.0877 \\
(0.0638)\end{array}$ & $\begin{array}{c}0.0811 \\
(0.0769)\end{array}$ & $\begin{array}{c}0.0600 \\
(0.0684)\end{array}$ & $\begin{array}{c}0.0461 \\
(0.0764)\end{array}$ & $\begin{array}{c}0.0580 \\
(0.0662)\end{array}$ & $\begin{array}{c}0.0672 \\
(0.0450)\end{array}$ \\
\hline $\begin{array}{l}\text { One Year Before Adoption of Castle Doctrine } \\
\text { Law }\end{array}$ & & & & $\begin{array}{l}-0.0557 \\
(0.0494)\end{array}$ & & \\
\hline Observations & 550 & 550 & 550 & 550 & 550 & 550 \\
\hline \multicolumn{7}{|c|}{ Panel C: Homicide (Negative Binomial - Unweighted) } \\
\hline Castle Doctrine Law & $\begin{array}{c}0.0565^{*} \\
(0.0331)\end{array}$ & $\begin{array}{l}0.0734^{* *} \\
(0.0305)\end{array}$ & $\begin{array}{c}0.0879^{* * *} \\
(0.0313)\end{array}$ & $\begin{array}{l}0.0783^{\star *} \\
(0.0355)\end{array}$ & $\begin{array}{l}0.0937^{* * *} \\
(0.0302)\end{array}$ & $\begin{array}{l}0.108^{* * *} \\
(0.0346)\end{array}$ \\
\hline $\begin{array}{l}\text { One Year Before Adoption of Castle Doctrine } \\
\text { Law }\end{array}$ & & & & $\begin{array}{l}-0.0352 \\
(0.0260)\end{array}$ & & \\
\hline Observations & 550 & 550 & 550 & 550 & 550 & 550 \\
\hline \multicolumn{7}{|l|}{ Panel D: Log Murder Rate (OLS - Weighted) } \\
\hline Castle Doctrine Law & $\begin{array}{l}0.0906^{* *} \\
(0.0424)\end{array}$ & $\begin{array}{l}0.0955^{* *} \\
(0.0389)\end{array}$ & $\begin{array}{l}0.0916^{* *} \\
(0.0382)\end{array}$ & $\begin{array}{l}0.0884^{\star *} \\
(0.0404)\end{array}$ & $\begin{array}{l}0.0981^{* *} \\
(0.0391)\end{array}$ & $\begin{array}{c}0.0813 \\
(0.0520)\end{array}$ \\
\hline $\begin{array}{l}\text { One Year Before Adoption of Castle Doctrine } \\
\text { Law }\end{array}$ & & & & $\begin{array}{l}-0.0110 \\
(0.0230)\end{array}$ & & \\
\hline Observations & 550 & 550 & 550 & 550 & 550 & 550 \\
\hline State and Year Fixed Effects & Yes & Yes & Yes & Yes & Yes & Yes \\
\hline Region-by-Year Fixed Effects & & Yes & Yes & Yes & Yes & Yes \\
\hline Time-Varying Controls & & & Yes & Yes & Yes & Yes \\
\hline Contemporaneous Crime Rates & & & & & Yes & \\
\hline State-Specific Linear Time Trends & & & & & & Yes \\
\hline \multicolumn{7}{|c|}{$\begin{array}{l}\text { Notes: Each column in each panel represents a separate regression. The unit of observation is state-year. Robust standard errors } \\
\text { are clustered at the state level. Negative binomial estimates are interpreted in the same way as those in a log-linear OLS model. } \\
\text { Time-varying controls include policing and incarceration rates, welfare and public assistance spending, median income, poverty } \\
\text { rate, unemployment rate, and demographics. Contemporaneous crime rates include larceny and motor vehicle theft rates. } \\
\text { Homicide data are from the published FBI Uniform Crime Reports, while murder data are from Return A of the FBI Master files. } \\
\text { * Significant at the } 10 \% \text { level } \\
\text { ** Significant at the } 5 \% \text { level } \\
\text { *** Significant at the } 1 \% \text { level }\end{array}$} \\
\hline
\end{tabular}


Table 6: The Effect of Castle Doctrine on Felony-Type Homicide, Proportion of Robberies Committed Using a Gun, and Justifiable Homicide by Private Citizens

\begin{tabular}{|c|c|c|c|c|c|c|}
\hline & 1 & 2 & 3 & 4 & 5 & 6 \\
\hline \multicolumn{7}{|c|}{$\begin{array}{l}\text { Panel A: Log Felony-Type and Suspected Felony Type Homicides } \\
\text { (OLS - Weighted) }\end{array}$} \\
\hline Castle Doctrine Law & $\begin{array}{l}0.0993 \\
(0.112)\end{array}$ & $\begin{array}{l}0.203^{*} \\
(0.109)\end{array}$ & $\begin{array}{l}0.220^{* *} \\
(0.0907)\end{array}$ & $\begin{array}{l}0.249^{* *} \\
(0.0992)\end{array}$ & $\begin{array}{l}0.222^{* *} \\
(0.0871)\end{array}$ & $\begin{array}{l}0.00121 \\
(0.0686)\end{array}$ \\
\hline $\begin{array}{l}\text { One Year Before Adoption of Castle Doctrine } \\
\text { Law }\end{array}$ & & & & $\begin{array}{c}0.106 \\
(0.0648)\end{array}$ & & \\
\hline Observations & 539 & 539 & 539 & 539 & 539 & 539 \\
\hline \multicolumn{7}{|l|}{$\begin{array}{l}\text { Panel B: Proportion of Robberies Using Gun } \\
\text { (OLS - Weighted) }\end{array}$} \\
\hline Castle Doctrine Law & $\begin{array}{l}0.0444^{* * *} \\
(0.0145)\end{array}$ & $\begin{array}{c}0.0218 \\
(0.0186)\end{array}$ & $\begin{array}{c}0.0187 \\
(0.0153)\end{array}$ & $\begin{array}{c}0.0227 \\
(0.0166)\end{array}$ & $\begin{array}{l}0.0183 \\
(0.0155)\end{array}$ & $\begin{array}{l}-0.00404 \\
(0.0133)\end{array}$ \\
\hline $\begin{array}{l}\text { One Year Before Adoption of Castle Doctrine } \\
\text { Law }\end{array}$ & & & & $\begin{array}{c}0.0130 \\
(0.00823)\end{array}$ & & \\
\hline Observations & 544 & 544 & 544 & 544 & 544 & 544 \\
\hline \multicolumn{7}{|l|}{$\begin{array}{l}\text { Panel C: Justifiable Homicide by Private Citizens } \\
\text { (OLS - Weighted, Dep. Variable }=\text { Count) }\end{array}$} \\
\hline Castle Doctrine Law & $\begin{array}{l}9.624^{* * *} \\
(3.310)\end{array}$ & $\begin{array}{l}6.028^{* *} \\
(2.450)\end{array}$ & $\begin{array}{l}4.550^{*} \\
(2.572)\end{array}$ & $\begin{array}{c}4.291 \\
(2.936)\end{array}$ & $\begin{array}{l}4.559^{*} \\
(2.493)\end{array}$ & $\begin{array}{c}0.835 \\
(1.802)\end{array}$ \\
\hline $\begin{array}{l}\text { One Year Before Adoption of Castle Doctrine } \\
\text { Law }\end{array}$ & & & & $\begin{array}{l}-0.854 \\
(2.006)\end{array}$ & & \\
\hline Observations & 550 & 550 & 550 & 550 & 550 & 550 \\
\hline \multicolumn{7}{|l|}{$\begin{array}{l}\text { Panel D: Justifiable Homicide by Private Citizens } \\
\text { (OLS - Unweighted, Dep. Variable }=\text { Count) }\end{array}$} \\
\hline Castle Doctrine Law & $\begin{array}{c}4.328^{* * *} \\
(1.467)\end{array}$ & $\begin{array}{l}3.370^{* *} \\
(1.300)\end{array}$ & $\begin{array}{l}3.200^{* *} \\
(1.202)\end{array}$ & $\begin{array}{l}2.908^{* *} \\
(1.350)\end{array}$ & $\begin{array}{l}3.239^{\star *} \\
(1.216)\end{array}$ & $\begin{array}{c}0.960 \\
(1.219)\end{array}$ \\
\hline $\begin{array}{l}\text { One Year Before Adoption of Castle Doctrine } \\
\text { Law }\end{array}$ & & & & $\begin{array}{l}-1.168 \\
(1.223)\end{array}$ & & \\
\hline Observations & 550 & 550 & 550 & 550 & 550 & 550 \\
\hline \multicolumn{7}{|l|}{$\begin{array}{l}\text { Panel E: Justifiable Homicide by Private Citizens } \\
\text { (Negative Binomial - Unweighted) }\end{array}$} \\
\hline Castle Doctrine Law & $\begin{array}{c}0.573^{* * *} \\
(0.210)\end{array}$ & $\begin{array}{l}0.428^{\star} \\
(0.244)\end{array}$ & $\begin{array}{c}0.283 \\
(0.235)\end{array}$ & $\begin{array}{c}0.219 \\
(0.254)\end{array}$ & $\begin{array}{c}0.324 \\
(0.228)\end{array}$ & $\begin{array}{l}\text { NA } \\
\text { NA }\end{array}$ \\
\hline $\begin{array}{l}\text { One Year Before Adoption of Castle Doctrine } \\
\text { Law }\end{array}$ & & & & $\begin{array}{l}-0.253^{*} \\
(0.147)\end{array}$ & & \\
\hline Observations & 550 & 550 & 550 & 550 & 550 & 550 \\
\hline State and Year Fixed Effects & Yes & Yes & Yes & Yes & Yes & Yes \\
\hline Region-by-Year Fixed Effects & & Yes & Yes & Yes & Yes & Yes \\
\hline Time-Varying Controls & & & Yes & Yes & Yes & Yes \\
\hline Contemporaneous Crime Rates & & & & & Yes & \\
\hline State-Specific Linear Time Trends & & & & & & Yes \\
\hline \multicolumn{7}{|l|}{$\begin{array}{l}\text { Notes: Each column in each panel represents } \\
\text { are clustered at the state level. Negative binor } \\
\text { Time-varying controls include policing and ince } \\
\text { rate, unemployment rate, and demographics. } \\
\text { Homicide data are from the published FBI Unif } \\
\text { NA indicates that the model did not converge. } \\
\text { enactment, or } 10.0 \text { if weighted by population. } \\
\text { * Significant at the } 10 \% \text { level } \\
\text { ** Significant at the } 5 \% \text { level } \\
\text { *** Significant at the } 1 \% \text { level }\end{array}$} \\
\hline
\end{tabular}


Web Appendix

Table A1: Differential Effects of Castle Doctrine Law by Treatment of Duty to Retreat and Civil Liability

\begin{tabular}{|c|c|c|c|c|c|c|c|c|c|c|c|c|}
\hline \multirow[b]{2}{*}{$\begin{array}{l}\text { Castle Doctrine Law That Removes Duty } \\
\text { to Retreat in Any Place }\end{array}$} & \multicolumn{2}{|c|}{ Log Burglary Rate } & \multicolumn{2}{|c|}{ Log Robbery Rate } & \multicolumn{2}{|c|}{$\begin{array}{l}\text { Log Aggravated } \\
\text { Assault Rate }\end{array}$} & \multicolumn{2}{|c|}{ Log Homicide Rate } & \multicolumn{2}{|c|}{$\begin{array}{c}\text { Proportion of } \\
\text { Robberies with a } \\
\text { Gun }\end{array}$} & \multicolumn{2}{|c|}{$\begin{array}{c}\text { Justifiable Homicide } \\
\text { by Private Citizens } \\
\text { (count) }\end{array}$} \\
\hline & $\begin{array}{l}0.0263 \\
(0.0266)\end{array}$ & $\begin{array}{c}0.0133 \\
(0.0218)\end{array}$ & $\begin{array}{l}0.00903 \\
(0.0267)\end{array}$ & $\begin{array}{l}0.0575^{*} \\
(0.0286)\end{array}$ & $\begin{array}{c}0.0225 \\
(0.0286)\end{array}$ & $\begin{array}{l}0.0547^{\star} \\
(0.0314)\end{array}$ & $\begin{array}{l}0.0668^{* \star} \\
(0.0289)\end{array}$ & $\begin{array}{l}0.109^{\star \star \star} \\
(0.0352)\end{array}$ & $\begin{array}{l}0.0347^{*} \\
(0.0186)\end{array}$ & $\begin{array}{l}-0.00381 \\
(0.0140)\end{array}$ & $\begin{array}{l}4.697^{* *} \\
(2.123)\end{array}$ & $\begin{array}{c}1.717 \\
(2.023)\end{array}$ \\
\hline Observations & 506 & 506 & 506 & 506 & 506 & 506 & 506 & 506 & 500 & 500 & 506 & 506 \\
\hline Panel B: Differential Effects by Whether th & $\begin{array}{l}\text { e Law Inclu } \\
\text { Log Burg }\end{array}$ & $\begin{array}{l}\text { des a Pres } \\
\text { lary Rate }\end{array}$ & $\begin{array}{r}\text { ption of } R \epsilon \\
\text { Log Robb }\end{array}$ & $\begin{array}{l}\text { easonabler } \\
\text { bery Rate }\end{array}$ & $\begin{array}{r}\text { Log Ags } \\
\text { Assau }\end{array}$ & $\begin{array}{l}\text { gravated } \\
\text { It Rate }\end{array}$ & Log Homic & icide Rate & \multicolumn{2}{|c|}{$\begin{array}{c}\text { Proportion of } \\
\text { Robberies with a } \\
\text { Gun }\end{array}$} & \multicolumn{2}{|c|}{$\begin{array}{c}\text { Justifiable Homicide } \\
\text { by Private Citizens } \\
\text { (count) }\end{array}$} \\
\hline $\begin{array}{l}\text { Castle Doctrine Law That Includes } \\
\text { Presumption of Reasonableness }\end{array}$ & $\begin{array}{l}0.00622 \\
(0.0307)\end{array}$ & $\begin{array}{l}0.0185 \\
(0.0210)\end{array}$ & $\begin{array}{l}0.00912 \\
(0.0301)\end{array}$ & $\begin{array}{c}0.0396 \\
(0.0307)\end{array}$ & $\begin{array}{c}0.0262 \\
(0.0315)\end{array}$ & $\begin{array}{l}0.0604^{* *} \\
(0.0264)\end{array}$ & $\begin{array}{l}0.0808^{* * *} \\
(0.0299)\end{array}$ & $\begin{array}{l}0.0831^{*} \\
(0.0492)\end{array}$ & $\begin{array}{l}0.0353^{*} \\
(0.0181)\end{array}$ & $\begin{array}{l}-0.0125 \\
(0.0136)\end{array}$ & $\begin{array}{l}5.806^{* *} \\
(2.652)\end{array}$ & $\begin{array}{l}-0.0621 \\
(2.360)\end{array}$ \\
\hline Other Castle Doctrine Law & $\begin{array}{l}0.0683^{* * *} \\
(0.0202)\end{array}$ & $\begin{array}{l}0.0188 \\
(0.0296)\end{array}$ & $\begin{array}{c}0.0322 \\
(0.0261)\end{array}$ & $\begin{array}{c}0.0699 \\
(0.0429)\end{array}$ & $\begin{array}{c}0.0606 \\
(0.0395)\end{array}$ & $\begin{array}{l}0.0215 \\
(0.0524)\end{array}$ & $\begin{array}{c}0.0814 \\
(0.0545)\end{array}$ & $\begin{array}{c}0.102 \\
(0.0615)\end{array}$ & $\begin{array}{c}0.0266 \\
(0.0242)\end{array}$ & $\begin{array}{c}0.0269 \\
(0.0296)\end{array}$ & $\begin{array}{c}0.633 \\
(2.124)\end{array}$ & $\begin{array}{c}0.387 \\
(2.133)\end{array}$ \\
\hline Observations & 550 & 550 & 550 & 550 & 550 & 550 & 550 & 550 & 544 & 544 & 550 & 550 \\
\hline Panel C: Effect of Castle Doctrine Law, Ex & $\begin{array}{r}\text { xcluding St } \\
\text { Log Burg }\end{array}$ & $\begin{array}{l}\text { tes That } \mathrm{Di} \\
\text { lary Rate }\end{array}$ & $\begin{array}{l}\text { Jot Also Re } \\
\text { Log Robb }\end{array}$ & $\begin{array}{l}\text { emove Civi } \\
\text { bery Rate }\end{array}$ & $\begin{array}{l}\text { ability } \\
\text { Log Ags } \\
\text { Assau }\end{array}$ & $\begin{array}{l}\text { gravated } \\
\text { It Rate }\end{array}$ & Log Homic & icide Rate & \multirow{2}{*}{\multicolumn{2}{|c|}{$\begin{array}{c}\text { Proportion of } \\
\text { Robberies with a } \\
\text { Gun } \\
0.0337^{\star *}-0.000340 \\
(0.0166) \quad(0.0143)\end{array}$}} & \multicolumn{2}{|c|}{$\begin{array}{c}\text { Justifiable Homicide } \\
\text { by Private Citizens } \\
\text { (count) }\end{array}$} \\
\hline $\begin{array}{l}\text { Castle Doctrine Law That Removes Civil } \\
\text { Liability }\end{array}$ & $\begin{array}{l}0.0310 \\
(0.0236)\end{array}$ & $\begin{array}{c}0.0200 \\
(0.0202)\end{array}$ & $\begin{array}{l}0.0183 \\
(0.0250)\end{array}$ & $\begin{array}{l}0.0528^{*} \\
(0.0298)\end{array}$ & $\begin{array}{l}0.0366 \\
(0.0293)\end{array}$ & $\begin{array}{c}0.0433 \\
(0.0294)\end{array}$ & $\begin{array}{l}0.0682^{* *} \\
(0.0297)\end{array}$ & $\begin{array}{l}0.0888^{* *} \\
(0.0424)\end{array}$ & & & $\begin{array}{l}3.809^{*} \\
(2.092)\end{array}$ & $\begin{array}{c}0.157 \\
(2.042)\end{array}$ \\
\hline Observations & 517 & 517 & 517 & 517 & 517 & 517 & 517 & 517 & 511 & 511 & 517 & 517 \\
\hline State and Region-by-Year Fixed Effects & Yes & Yes & Yes & Yes & Yes & Yes & Yes & Yes & Yes & Yes & Yes & Yes \\
\hline Time-Varying Controls & Yes & Yes & Yes & Yes & Yes & Yes & Yes & Yes & Yes & Yes & Yes & Yes \\
\hline State-Specific Linear Time Trends & & Yes & & Yes & & Yes & & Yes & & Yes & & Yes \\
\hline
\end{tabular}

State-Specific Linear Time Trends

Yes Yes

Ytate level. The unit of

Notes: Each column in each panel represents a regression, each of which is weighted by state population. Robust standard errors are clustered at the state level. The unit of
observation is state-year. Time-varying controls include policing and incarceration rates, welfare and public assistance spending, median income, poverty rate, unemployment rate, and demographics.

* Significant at the $10 \%$ leve

** Significant at the $5 \%$ level

*** Significant at the $1 \%$ level 
Table A2: Justifiable Homicide by Police

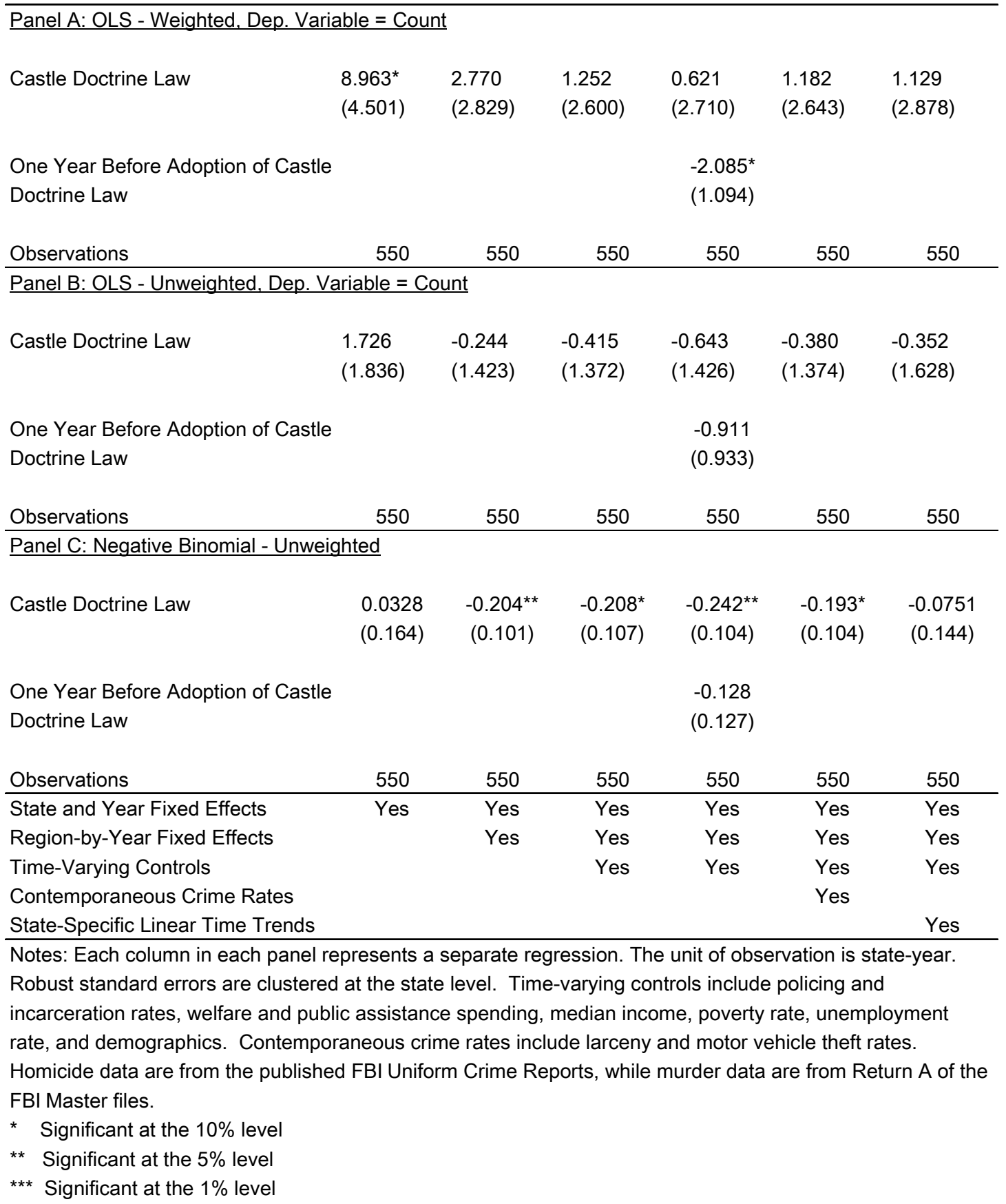

